\title{
Produk teenoor proses tydens akademiese redigering: Opmerkings as aanduiders van redigeergerigtheid
}

\author{
Amanda Lourens \\ Departement Afrikaans en Nederlands, Stellenbosch Universiteit, Suid-Afrika \\ Email: alourens@sun.ac.za
}

\section{Opsomming}

Omdat die redigering van akademiese tekste in Suid-Afrika gekenmerk word deur 'n gebrek aan standaardisering, is 'n verkennende beskrywing van redigeerders se werklike aktiwiteite tydens die redigering van hierdie tekste 'n nodige stap in die rigting van die formulering van riglyne of standaarde vir die redigering van akademiese tekste (Kruger en Bevan-Dye 2010). Die huidige studie gebruik die onderskeid tussen die sogenaamde produk- en prosesbenadering tot redigering as uitgangspunt om werklike redigeerprodukte te ondersoek. Die produkgeoriënteerde benadering plaas die klem op die eindproduk, sonder dat dialoog met die skrywer noodsaaklik geag word. Dit staan teenoor die prosesgeoriënteerde benadering wat eerder fokus op die teksredigeerder se rol as fasiliteerder in 'n proses wat die student se betrokkenheid by sy/haar eie skryfproduk beklemtoon. Moderne woordverwerkingstegnologie bied die funksie van opmerkings ("comments") as 'n ruimte waarin interaksie met die student as skrywer moontlik is en só die prosesbenadering sigbaar maak. Die huidige ondersoek het ten doel om redigeerders van akademiese tekste (tesisse of proefskrifte) se benutting van die opmerkingfunksie in MS Word te beskryf en om afleidings rakende die redigeerder(s) se benadering te maak. Drie geredigeerde tesisse word empiries ondersoek. Dit blyk dat opmerkings wel deurgaans benut word, alhoewel die drie tesisse nie in dieselfde mate blyke gee van ' $n$ benutting van opmerkings nie. Alhoewel die gebruik van die opmerkings in die drie redigeerprojekte op 'n aanwesigheid van die prosesbenadering dui, word hierdie benadering nie suiwer toegepas nie. Die uitkomste van hierdie verkennende studie dui nie slegs die rigting aan vir toekomstige navorsing nie, maar dui ook aan dat toekomstige standaardiseringsprosesse veral moet besin oor die redigeerder se rol en professionele identiteit, asook die verhouding tussen studieleier, student en redigeerder. Die opleiding van redigeerders behoort ook die eise van akademiese redigering as 'n spesifieke soort redigering te hanteer.

Sleutelwoorde: prosesbenadering tot redigering, produkbenadering tot redigering, redigeerstandaarde, woordverwerkingstegnologie, opmerkings 


\section{Product versus process during academic editing: Comments as indicators of editing orientation}

\section{Extended abstract}

The need for academic editing indicates an international point of growth for the editing industry, as pointed out by Macdonald (2008). This statement is motivated by two trends: Students fail to meet the standards of academic writing required on a postgraduate level; also, many students have to write in English, although it is their second or even third language. Tertiary institutions have divergent guidelines for the editing of academic texts, leading to a worldwide lack of standardisation regarding the editing of these texts. Hence, the field of academic editing is in need of professional discourse, research and eventually greater levels of standardisation.

Valuable work on the standardisation of professional editing - including academic editing has already been done by the Institute of Professional Editors (IPEd) (2010), the Editors' Association of Canada (EAC) (2009) as well as the Council of Australian Societies of Editors (CASE) (2013). Law (2011) has made an important local contribution towards the establishment of core standards for the South African editing practice, but the development of South African standards for the editing of academic texts remains an area that is still in need of in-depth inquiry.

Based on professional discussions on academic editing, a few key areas for the South African discourse on academic editing come to the fore. These include: the matter of the standardisation of academic editing; the question whether editors can and should fulfil a developmental role regarding students' writing skills; and the debate on where the borders of ethical academic editing are to be traced. The answers to these questions are closely related to perceptions of the editing task. Following the ideas set forth by Kruger and Bevan-Dye (2010) on the process- and product-oriented approach to editing, the editor's perception of his or her task might be projected as situated on a continuum with respectively the process- and product-oriented approach as the two extremes. While a product-oriented approach focuses on the textual product without dialogue with the writers necessarily being taken into account, the process-oriented approach focuses on the role of the text editor as a facilitator in a process that emphasises students' involvement in their own writing.

The study by Kruger and Bevan-Dye (2010) shows that South African editors identify with a product-oriented approach to their work, rather than a process-oriented approach. The authors, however, point out that perceptions are not always reliable indicators of practical outputs. Therefore Kruger and Bevan-Dye (2010) call for an investigation into what editors really do when editing academic texts - do their real-life actions reveal a process- or a product-oriented approach?

This call has given rise to the conceptualisation of a larger project that will investigate what actually happens during academic editing. The current study investigates a component of this larger project and focuses on one activity during academic editing, namely the use of the comments function of word-processing programmes in order to communicate with the student. As a theoretical point of departure, the study draws on the ideas of Hill (2011) regarding editors' problem solving activities. It is proposed that communication with the writer (in this case the student) by means of the electronic comments function of word processing programmes can be seen as an indicator of the editor's acceptance of a process-oriented approach to the editing 
task. Although the IPEd guidelines for the editing of theses advise against electronic editing, the current study views electronic editing as a reality of the technology-driven modern world, and proposes that the editor's approach to the editing task, rather than the medium, is crucial to determine whether there will be any learning gained by the student. The textual space of the comment is therefore, for the purposes of this study, viewed as a space that facilitates interaction between student and editor, so that a process-oriented approach to the editing task is realised in concrete terms whenever the editor chooses to insert a comment into a student's text.

Accordingly, the following problem statement for the current study is put forward: How can the use of the comments function by editors of academic texts be described, and which conclusions regarding the editing approaches of the individual editors can be made?

The following four research questions are presented in order to shape the study and to obtain specific results:

i. $\quad$ Do editors use the comments function in MS Word?

ii. Which types of textual problems do the comments address? To which extent are editors working in accordance with the international guidelines regarding the handling of these different types?

iii. What is the nature of the comments that are presented, i.e. are there different types of comments that can be distinguished?

iv. Which conclusions can be drawn regarding the editors' orientation?

The study follows an empirical methodology and three edited theses (all written in English in different departments at Stellenbosch University) are investigated with reference to the four research questions. Two theses were edited by private editors (both trained at Stellenbosch University) and one thesis was edited by the Language Service of Stellenbosch University. The validity and generalizability of the study is compromised by the fact that all three theses have ties with Stellenbosch University. Bias might also have been introduced by the fact that the three theses were chosen on the basis that they have been subjected to a comprehensive edit. Moreover, the many variables impacting on the example texts limit their comparability.

Regarding the question on the editors' use of the comments function, it was found that the three editors of the example texts all make use of comments, as indicated by the results that vary between 0,11 and 3,16 comments per 300 words, with an arithmetic mean of 1,00 for Thesis 1 , 1,91 for Thesis 2 and 0,24 for Thesis 3 . The arithmetic mean for the three examples is 1,05 comments per 300 words, indicating that the comments function is used in the example texts.

Regarding the question on the categories of textual problems addressed by the comments, it is found that comments related to issues on the levels of copyediting $(48,53 \%)$ and content $(37,87 \%)$ occur most frequently. Comments related to structural $(6,25 \%)$ and stylistic issues $(5,88)$ are limited, while comments related to consistency issues are severely limited $(1,47 \%)$. With regards to the international guidelines on the ethical handling of academic texts, it is found that the editors of Thesis 1 and Thesis 3 deviate from these guidelines by sometimes inserting additions themselves. The editor of Thesis 2 also deviates from the guidelines by asking questions on the level of content that belong to the domain of the supervisor. 
The investigation on the nature of the comments shows that two main categories of comments are to be discerned, based on whether the editor has made a decision or not. These two categories can be subdivided into a total of 11 smaller groups. Comments that are not based on a decision by the editor and which leaves room for the student to engage with his/her own writing are dominant (91,08\% for Thesis $1,100 \%$ for Thesis 2 and 55,87\% for Thesis 3 ).

A qualitative analysis of the comments reveals that the editor of Thesis 1 formulated the comments in a way that facilitates the student's own learning. The editor of Thesis 2 emphasizes technical aspects such as references, but also with the purpose of challenging the student to find the solution. The comments in Thesis 3 reveal a greater emphasis on the product than the other two edited theses.

In relation to editors' choice of a process or product approach the findings indicate that all three editors are inclined towards a process-oriented approach based on the analysis of the comments, although a product-oriented approach is also observed, especially in Thesis 3. Further research may elucidate whether a hybrid approach in editing, as in Thesis 3, is regularly observed, and which factors may contribute to such an approach. Further studies may also investigate whether specific editing activities are the result of the conscious adoption of a particular approach to editing.

The differences between the editors can be summarised as certain strategies that the individual editors employ during their editing work, making it possible to provide brief descriptions of the individual editing styles. The editor of Thesis 1 is found to have a supportive style, and the dominance of questions as comments shows that the editor strives to cultivate reflection by the student - thereby assuming a process-oriented approach. The editor of Thesis 2 is shown to have a more direct, instructive style, as reflected by a preference for "simple comments", meaning that the student has to interpret the comment before attempting to solve the problem independently. Once again, this editor follows a process-oriented approach. The editor of Thesis 3 displays a tentative style where the student is often cast in the role of reviser, as reflected by the strong presence of comments asking the student to approve a certain textual change indicating the presence of a product-oriented approach.

The outcomes of this exploratory study can be integrated into future work towards the standardization of academic editing in South Africa. Not only should such work incorporate a reflection on the role and professional identity of the editor, but it should also take account of the relationship between supervisor, student and editor. Lastly, the training of editors is implied in the sense that syllabi can be refined in order to train students for the specific requirements of academic editing.

Key words: process-oriented approach to editing, product-oriented approach to editing, editing standards, word-processing technology, comments 


\section{Inleiding en agtergrond}

Die aanvraag na die redigering van akademiese tekste ${ }^{1}$ dui op 'n internasionale groeipunt binne die taal- en spesifiek die redigeerpraktyk, soos Macdonald (2008) aandui. Sy motiveer hierdie stelling deur te wys op twee faktore wat internasionaal meewerk om die groeiende vraag na akademiese redigering te voed: Nagraadse studente se gebrekkige akademiese skryfvaardighede, ${ }^{2}$ saam met die tendens dat al hoe meer studente in Engels - hulle tweede of selfs derde taal - skryf, lei daartoe dat hulle tekste deur professionele redigeerders versorg moet word alvorens dit geskik is om vir eksaminering ingelewer te word (Macdonald 2008:3). Omdat hoëronderwysinstellings wêreldwyd se riglyne vir die redigering van akademiese tekste egter geweldig uiteenlopend en daarom ook verwarrend is (Macdonald 2008:3-4), is daar in die veld van akademiese redigering ' $n$ dringende behoefte aan vakkundige gesprek, navorsing en uiteindelik groter standaardisering.

Waardevolle werk - in die vorm van die daarstelling van standaarde vir redigering, insluitende akademiese redigering - is internasionaal reeds deur die Institute of Professional Editors $(\text { IPEd })^{3}(2010)$, die Editors' Association of Canada (EAC) (2009) asook die Council of Australian Societies of Editors (CASE) (2013) gedoen. Law (2011), wat plaaslik 'n groot bydrae gelewer het in die daarstelling van kernstandaarde vir die Suid-Afrikaanse redigeerpraktyk, noem dat die waarde van 'n stel kernstandaarde daarin lê dat dit die status van die redigeerpraktyk kan verhoog, maar terselfdertyd ook kan meewerk om kliënte se verwagtinge - en daarmee saam die redigeerprodukte wat in die praktyk gelewer word - meer eenvormig te maak. Wat die Suid-Afrikaanse situasie betref, wys Law (2011) egter daarop dat alhoewel die plaaslike redigeerpraktyk met vrug van die internasionale riglyne kan kennis neem, dit nie sonder meer van toepassing op die Suid-Afrikaanse konteks gemaak kan word nie, soos in die volgende paragraaf toegelig word. Alhoewel Law (2011) se werk 'n leemte vul wat die daarstelling van algemene redigeerstandaarde betref, is die ontwikkeling van SuidAfrikaanse standaarde vir die redigering van akademiese tekste 'n terrein wat nog deurtastend ondersoek moet word.

Ofskoon die internasionale tendense soos hier bo deur Macdonald (2008) genoem ook in SuidAfrika herken word, is probleme rakende akademiese skryfvaardighede en die hantering van akademiese tekste in Suid-Afrika selfs meer kompleks as in die res van die wêreld. Die SuidAfrikaanse toneel word gekenmerk deur groot historiese en eietydse verdeeldhede wat betref bronne, vaardighede, verwagtinge en geleenthede. ${ }^{4}$ Riglyne vir Suid-Afrika behoort dus teen hierdie agtergrond geformuleer te word. Dit is voorts ook nodig dat stappe in die rigting van die standaardisering van akademiese redigering deur gerigte navorsing onderlê word: Huidige persepsies en praktyke behoort op 'n wetenskaplike wyse beskryf te word alvorens daar voortgegaan kan word om te besin oor watter praktyke spesifiek aangedui is vir akademiese redigering in Suid-Afrika.

\footnotetext{
${ }^{1}$ Met akademiese tekste word hier spesifiek bedoel tekste wat deur studente aan hoëronderwysinstellings geproduseer word met die oog op die verwerwing van gevorderde grade, met ander woorde tesisse en proefskrifte.

${ }^{2}$ Ook Van Aswegen (2007) wys op nagraadse studente se gebrekkige akademiese skryfvaardighede.

3 Australië.

${ }^{4}$ Kruger en Bevan-Dye (2013) sê dat die voltooiing van nagraadse studies in Suid-Afrika gekniehalter word deur uiteenlopende uitdagings, waaronder gebrekkige taalvaardighede asook swak akademiese geletterdheid, die niegebruik van moedertale in akademiese omgewings, leeromgewings wat nie oor genoegsame bronne beskik nie, tesame met die algemene sosiale uitdagings wat met ontwikkelende lande geassosieer word.
} 
Dat die vakkundige gesprek oor akademiese redigering in Suid-Afrika reeds 'n aanvang geneem het, blyk duidelik uit enkele onlangse werksessies oor die onderwerp. 'n Werksessie van die Professional Editors' Group (PEG) in $2010^{5}$ het die volgende belangrike kwessies rakende akademiese redigering uitgelig wat deur navorsers, taalpraktisyns en ander rolspelers (soos studieleiers en universiteite) verreken moet word: “... [T] he role of editors in the thesis production process needs to be recognised, better understood and formalised by faculties"; "[e]ditors should be drawn into the process from the outset if it is to be truly developmental, especially from the honours level"; en "PEG should develop guidelines akin to those of the Canadian and Australian editors' associations but which take into account the particular circumstances we're faced with in South Africa" (my kursivering) (Linnegar 2010).

Ook tydens ' $\mathrm{n}$ werksessie van die US Taaldiens in $2011^{6}$ is enkele rigtinggewende vrae geïdentifiseer wat in verdere gesprekke en studies aangeraak behoort te word. Woordelikse insette van die deelnemers sluit in: "Waar lê die perke van wat 'n mens mag/moet doen en wat nie?"; “[i]s daar sin daarin om vir 'n student aan te dui om self deurgaans sekere veranderinge aan te bring (byvoorbeeld hoofletters, of ander sake wat met konsekwentheid te make het) as dit duidelik is dat die student nie 'n oog vir sulke besonderhede het nie?" en "[i]n watter mate is die redigering van 'n tesis 'n opvoedingstaak?" (my kursivering) (Hansen 2011).

Van die sleuteltemas vir die Suid-Afrikaanse konteks wat uit hierdie werksessies sigbaar raak, is dus die kwessie van die standaardisering van akademiese redigering, die vraag of redigeerders ook 'n ontwikkelingsrol kan en behoort te speel wat studente se skryfvaardighede betref, asook die vraag na waar die grense van etiese akademiese redigering lê. Antwoorde hierop hou ten nouste verband met sienings oor die aard van die redigeertaak - overgesetsynde, die standaardisering van akademiese redigering sal verband hou met die wyse waarop die redigeerder se taak gekonseptualiseer word. Na aanleiding van Kruger en Bevan-Dye (2010) se onderskeid tussen die sogenaamde produk- en prosesbenadering, kan die redigeerder se siening van sy/haar taak voorgestel word as geleë op 'n kontinuum met onderskeidelik die produk- en die prosesgeoriënteerde benadering tot redigering as die twee ekstreme daarvan. Kruger en Bevan-Dye (2010:164) se onderskeid tussen die twee benaderings behels dat 'n produkgeoriënteerde siening op die geredigeerde eindproduk fokus, terwyl 'n prosesgeoriënteerde siening behels dat die redigeerder eerder ' $n$ fasiliterende rol in die student se skryf-as-leer-proses speel. ${ }^{7}$

Vir die doel van die huidige studie is dit nodig dat daar gekyk word na hoe die redigeerder se ingryping met onderskeidelik die proses- en die produkbenadering verband hou. Ingryping kan op 'n tekstuele vlak plaasvind, maar daar kan ook "meta-ingryping" (ingryping op 'n metavlak) wees. Eersgenoemde beteken dat tekstuele veranderinge aangebring word, terwyl laasgenoemde beteken dat daar met die student gekommunikeer word om byvoorbeeld tekstuele wysigings toe te lig, die student te help om self probleme op te los of die student bewus te maak van foute wat herhaaldelik voorkom. Tydens akademiese redigering is groot ingrepe op tekstuele vlak nie altyd aangedui nie, omdat die student se eie skryfvaardighede ook beoordeel moet word. Groot ingrepe lê dus buite die grense van etiese akademiese redigering. Indien die

\footnotetext{
${ }^{5}$ Gefasiliteer deur Haidee Kruger van die Skool vir Tale, Noordwes-Universiteit, Vaaldriehoekkampus.

${ }^{6}$ Gefasiliteer deur Amanda Lourens van die Departement Afrikaans en Nederlands, Universiteit Stellenbosch.

${ }^{7}$ Alhoewel Kruger en Bevan-Dye (2010) hierdie twee benaderingswyses nie as die twee ekstreme van 'n kontinuum beskryf nie, is dit myns insiens wel 'n nuttige voorstelling, omdat dit onwaarskynlik is dat enige redigeertak in die praktyk volkome proses- of volkome produkgerig sal wees.
} 
akademiese redigeerder ingestel is op 'n prosesbenadering waar die student se leerproses beklemtoon word, sal 'n groter mate van ingryping op metavlak waarskynlik sigbaar raak, omdat die redigeerder met die student sal kommunikeer om sy/haar leerproses te fasiliteer. Terselfdertyd sal die ingryping op die tekstuele vlak dalk selfs verminder, omdat die redigeerder van die student sal verwag om meer wysigings self aan te bring. 'n Produkbenadering tot akademiese redigering sal waarskynlik gekenmerk word deur 'n beperkte mate van ingryping op metavlak, omdat kommunikasie met die student nie as belangrik geag word nie en die tekstuele produk van primêre belang is. Terselfdertyd kan ingryping op tekstuele vlak ook beperk wees, omdat die redigeerder daarvan bewus is dat die student se eie skryfvaardighede beoordeel word.

Teen hierdie agtergrond ontstaan die vraag in watter mate dit wenslik is dat die redigeerder 'n fasiliterende rol ten opsigte van die student se skryfvaardighede speel deur byvoorbeeld op metavlak met die student te kommunikeer. Op 'n praktiese vlak beteken dit dat riglyne vir akademiese redigering nodig is, sodat redigeerders kan weet watter mate van tekstuele ingryping wenslik is, maar dat hulle ook riglyne het wat betref kommunikasie met die student. Alvorens sulke riglyne neergelê kan word, moet redigeerders se siening van hulle eie taak ondersoek word, maar die sienings van byvoorbeeld studieleiers en hoëronderwyskundiges moet ook in ag geneem word.

Kruger en Bevan-Dye (2010) se belangrike studie waarin praktiserende redigeerders se persepsies oor die redigering van tesisse en proefskrifte ondersoek word, bring aan die lig dat Suid-Afrikaanse redigeerders van akademiese tekste 'n produkgeoriënteerde eerder as prosesgeoriënteerde siening van hulle werk het. Die redigeerders sien hulle eie rol as beperk, en dui aan dat werk op die vlakke van kopieredigering en styl aanvaarbaar is, terwyl ingryping op die vlakke van struktuur en inhoud ${ }^{8}$ onaanvaarbaar is.

Die studie van Kruger en Bevan-Dye (2013) wat op die 2010-studie volg, ondersoek SuidAfrikaanse studieleiers se persepsies oor die redigeerder se rol. Daar word bevind dat SuidAfrikaanse studieleiers ' $n$ meer beperkte siening van die redigeerder se rol het as wat die redigeerders self het. Studieleiers beskou die redigeerder se werk as hoofsaaklik beperk tot die vlak van kopieredigering, en beskou werk op die stilistiese vlak as die student se eie verantwoordelikheid. Ingryping op die vlakke van struktuur en inhoud word deur die studieleiers as ongewens beskou, alhoewel die studieleiers se siening van hierdie aspekte tog effens minder beperkend is as dié van redigeerders self. Die resultate van die twee groepe (redigeerders en studieleiers) wys uiteindelik op 'n uiters beperkte siening van die redigeerder se rol - die redigeerder is naamlik slegs die korrigeerder van basiese foute op die vlak van kopieredigering.

Kruger en Bevan-Dye (2013) stel dit wel in hulle gevolgtrekking dat studieleiers se baie beperkte siening van die redigeerder se rol saamval met verskeie Suid-Afrikaanse hoëronderwysinstellings se riglyne vir akademiese redigering. Aan die ander kant is daar wel ook hoëronderwysinstellings wat die redigeerder se rol as meer omvattend sien. As voorbeeld van laasgenoemde verwys Kruger en Bevan-Dye (2010:156-7) na die Taaldiens van die Universiteit Stellenbosch wat die redigeerder toelaat om 'n ontwikkelingsrol ten opsigte van studente se skryfwerk te speel, deurdat die student byvoorbeeld op probleme ten opsigte van

\footnotetext{
${ }^{8}$ Mossop (2007) se onderskeid tussen vier soorte redigering (kopie-, stilistiese, strukturele en inhoudelike redigering) is die grondslag van Kruger en Bevan-Dye (2010) se indeling.
} 
sin- en paragraafstruktuur gewys word. Sulke botsende sienings wys duidelik op 'n behoefte aan standaardisering wat betref beleid en praktyke aan Suid-Afrikaanse hoëronderwysinstellings (Kruger en Bevan Dye 2013:895).

Daar kan ook geargumenteer word dat studieleiers se persepsies nie noodwendig 'n refleksie van die ideale praktyk op 'n gegewe tydstip en binne 'n sekere konteks is nie. Die studieleiers wat aan die studie deelgeneem het, assosieer hulle sterk met 'n tradisionele studieleidingsmodel, waarvolgens die student primêr daarvoor verantwoordelik is om/sy haar navorsingsvaardighede (ook skryfvaardighede) te ontwikkel. Kruger en Bevan-Dye (2013:896) wys dan tereg daarop dat, gegee die Suid-Afrikaanse situasie waar nagraadse skryftake besondere uitdagings vir studente inhou, die tyd moontlik ryp is om tradisionele modelle van studieleiding uit te daag en te argumenteer ten gunste van 'n groter ondersteunende rol deur die redigeerder. Sulke toekomstige werk kan egter slegs moontlik gemaak word deur 'n volledige verkenning van huidige akademiese redigeerpraktyke.

In die 2010-studie wys die outeurs daarop dat die redigeerders wat in die steekproef ingesluit is, se menings oor hulle rol tydens akademiese redigering nie noodwendig korreleer met hulle redigeerpraktyk nie. Om hierdie rede stel Kruger en Bevan-Dye (2010:164) voor dat verdere studies aangedui word ten einde te probeer vasstel wat redigeerders wérklik doen tydens hulle redigering van akademiese tekste - word daar in die praktyk 'n proses- of 'n produkbenadering gevolg?

Teen die agtergrond van Kruger en Bevan-Dye (2010) se oproep is 'n groter projek gekonseptualiseer met die doel om 'n oorsig te gee van wat werklik tydens akademiese redigering gebeur, met ander woorde, of 'n proses- of produkbenadering gevolg word. Anders gestel, hoe gee redigeerders in hulle redigeerpraktyk gestalte aan hulle rol? Die huidige studie ondersoek 'n komponent van hierdie groter projek, en fokus op een aktiwiteit tydens akademiese redigering - naamlik die gebruik van die kommentaarfunksie in woordverwerkingsprogramme om met die student te kommunikeer. In die huidige studie word geraak aan die moontlikheid dat opmerkings in der waarheid op 'n kontinuum lê met die prosesen produkbenadering as die twee ekstreme. Wanneer die opmerking ingespan word om ook byvoorbeeld inligting oor die redigeerder se eie prosesse te verskaf (byvoorbeeld om 'n redigeerbesluit te motiveer of 'n wysiging te verduidelik), lê die opmerking waarskynlik nader aan die produkbenadering, omdat die wysiging reeds aangebring is. Nietemin word daar met die student gekommunikeer, al is dit dalk meer met die doel om die redigeerder se eie proses sigbaar te maak. Wanneer die redigeerder egter nie 'n besluit neem nie, en die opmerking daarop gerig is om die student te lei om self die besluit te neem, lê die opmerking nader aan die prosesbenadering. Die feit dat die opmerking egter ingesluit word, ongeag of ' $n$ wysiging reeds aangebring is of nie, dui egter daarop dat die redigeerder kommunikasie op metavlak met die student nodig ag. Om hierdie rede sal 'n opmerking dus altyd in 'n mate prosesgerig wees, en vir die doel van die huidige studie word die blote teenwoordigheid van 'n opmerking reeds as 'n aanduider van 'n prosesbenadering gesien.

$\mathrm{Na}$ afloop van hierdie studie kan verdere verbandhoudende aktiwiteite en kwessies ondersoek word, wat ook deur die huidige studie uitgelig sal word. Hierdie ondersoeke kan die grondslag vorm vir wetenskaplike gesprekvoering en die uiteindelike daarstelling van 'n stel werkbare en etiese riglyne wat die realiteite van die Suid-Afrikaanse tersiêre onderrigkonteks in ag neem - 
'n proses wat volgens Kruger en Bevan-Dye (2010:155) onder meer op konsultasie met die betrokke partye berus. ${ }^{9}$

Hill (2011) bied 'n raamwerk vir die beskrywing van redigeerders se probleemoplossingsaktiwiteite wanneer hulle redigeer. Hierdie raamwerk ${ }^{10}$ neem as vertrekpunt dat 'n redigeerder kan kies om met die skrywer ${ }^{11}$ van die teks te kommunikeer, eerder as om bloot veranderinge aan te bring sonder om die veranderinge byvoorbeeld toe te lig of alternatiewe oplossings voor te stel. Kommunikasie met die skrywer (in hierdie geval die student) deur middel van die elektroniese opmerkingfunksie van woordverwerkingsprogramme word, soos hierbo genoem, in hierdie studie gesien as 'n aanduider van die redigeerder se aanvaarding van 'n prosesbenadering tot die redigeertaak. Die funksie bied die moontlikheid om byvoorbeeld 'n bepaalde korreksie te verduidelik, sodat die student begryp waarom sy/haar oorspronklike aanbod problematies is. Ook kan die redigeerder bepaalde herhalende foute uitwys sodat die student bemagtig word om die probleem self in die toekoms op te los.

Alhoewel hierdie studie aanvaar dat redigering merendeels elektronies geskied, ${ }^{12}$ is dit nodig om te noem dat daar in die Australiese standaarde vir akademiese redigering teen die praktyk van elektroniese redigering gewaarsku word (IPEd 2010). Die PEG-werksessie van 2010 kom tot dieselfde slotsom, wat Linnegar (2010) soos volg opsom: "There are risks inherent in editing electronically using, for example, Microsoft Word's Track Changes function (students can simply 'accept all' without engaging with the editor's corrections, and learn nothing from their input). Some attendees recommended hard copy editing as standard practice instead." Hierdie uitsprake aanvaar egter dat die redigeerder noodwendig alle veranderinge elektronies aanbring en nie met die student daaroor kommunikeer nie; ook verreken dit nie die moontlikheid dat die student veranderinge op die sigkopie bloot klakkeloos kan implementeer nie. Daar word dus in hierdie studie geargumenteer dat die redigeerder se benaderingswyse tot die redigeertaak bepalend is, en die gekose medium van minder belang is.

Om op sigkopie te redigeer, is ook nie 'n realistiese opsie in die hedendaagse wêreld nie - die student en redigeerder is dikwels geografies ver van mekaar verwyder en die hantering van sigkopie is in sulke gevalle ' $\mathrm{n}$ beslommernis. Foute sluip ook maklik in wanneer die student die veranderinge self op die finale kopie moet aanbring. Die moontlikhede van die woordverwerkingstegnologie behoort veel eerder gesien te word as kreatiewe opsies wat byvoorbeeld die redigeerder se keuse vir die prosesbenadering kan ondersteun. So kan die tekstuele ruimte van die opmerkingfunksie beskou word as 'n ruimte wat spesifiek die doel van interaksie tussen skrywer (student) en redigeerder dien en konkreet meewerk tot 'n prosesbenadering.

\footnotetext{
${ }^{9}$ Hiermee word heel moontlik bedoel redigeerders, hoëronderwyskundiges, studieleiers en nagraadse studente. Organisasies (bv. PEG en SAVI) wat redigeerders in Suid-Afrika verteenwoordig, kan ook hier ingereken word.

${ }^{10}$ Die raamwerk word meer uitvoerig in afdeling 3 bespreek.

${ }^{11}$ In die geval van akademiese redigering word daar na alle waarskynlikheid met die student self gekommunikeer. Tydens die redigering van ander tekssoorte mag daar eerder met die opdraggewer (bv. die uitgewer) gekommunikeer word.

${ }^{12}$ Kruger en Bevan-Dye (2010) bevind dat 75,7\% van die redigeerders wat in hulle studie betrek is, wel 'n woordverwerkingsprogram gebruik om tekste elektronies te redigeer.
} 


\section{Doelstelling, probleemstelling en navorsingsvrae}

Alvorens die uiteindelike gesprek oor standaarde vir akademiese redigering in Suid-Afrika gevoer kan word, is ' $n$ behoorlike verkenning van die stand van sake nodig. Die huidige studie het dus ten doel om uitvoering te gee aan Kruger en Bevan-Dye se oproep om 'n verkenning van redigeerders se werklike aktiwiteite. Dit gaan hier oor 'n eerste en 'n verkennende beskrywing van redigeerders se werklike aktiwiteite tydens die redigering van akademiese tekste. Die resultate, alhoewel voorlopig, behoort die veld vir verdere studies te omlyn en die gebreke van die huidige navorsing behoort verdere studies te motiveer. Die uitkomste van die studie kan voorts gebruik word om te besin oor die redigeerder se rol en professionele identiteit, en het implikasies vir die opleiding van redigeerders deurdat sillabusinhoude verfyn kan word om studente spesifiek op te lei in die redigering van akademiese tekste. Hierdie studie word vervolgens gesien as die eerste in 'n reeks ondersoeke om die veld vollediger te karteer en wat uiteindelik kan uitloop op aanbevelings vir akademiese redigering in Suid-Afrika.

Die volgende probleemstelling word aangebied: Hoe kan redigeerders van akademiese tekste (tesisse of proefskrifte) se benutting van die opmerkingfunksie in MS Word beskryf word, en watter afleidings oor die redigeerder(s) se benadering kan daaruit gemaak word?

Ten einde die studie te rig en spesifieke resultate te verkry, word die volgende navorsingsvrae gestel:

i. Word opmerkings met behulp van MS Word deur die redigeerders van tesisse en/of proefskrifte benut?

ii. Watter soorte tekstuele probleme ${ }^{13}$ word deur die opmerkings betrek? In watter mate strook redigeerders se hantering van hierdie probleme met internasionale riglyne in hierdie verband?

iii. Wat is die aard van die opmerkings wat aangebied word, met ander woorde, is daar verskillende soorte opmerkings ${ }^{14}$ onderskeibaar? Indien wel, hoeveel van elke soort opmerking word aangetref - onderskeidelik in die individuele gevallestudies asook wanneer die gevallestudies gesamentlik beskou word?

iv. Watter afleidings kan gemaak word wat betref die navolging van die produk- en/of die prosesbenadering?

\section{Metodologie}

\subsection{Algemene benadering}

Drie geredigeerde tesisse ${ }^{15}$ is bekom en elk is empiries aan die hand van die vier navorsingsvrae ondersoek. Omdat die navorsing beskrywend en verkennend van aard is, is daar besluit om 'n gevallestudie-raamwerk te gebruik, waarbinne daar van kwalitatiewe ontledings - hoofsaaklik teksanalise - sowel as basiese beskrywende statistiese gegewens gebruik gemaak is. Op hierdie manier kan 'n indruk gevorm word van die tendense in hierdie drie voorbeelde.

\footnotetext{
${ }^{13}$ Met soorte tekstuele probleme word bedoel dat tekstuele probleme op verskillende vlakke van die teks onderskei kan word, byvoorbeeld probleme op inhoudelike, strukturele of stilistiese vlak.

${ }^{14}$ Daar word gekyk of daar verskillende soorte opmerkings onderskei kan word, eerstens op grond van of 'n redigeerbesluit reeds geneem is. Verder word fyner kategorieë onderskei op grond van die taalhandeling in die opmerking self - is dit byvoorbeeld 'n bevel of 'n verduideliking?

${ }^{15}$ Geredigeer deur verskillende redigeerders.
} 
Wat die eerste navorsingsvraag (oor die benutting van opmerkings) betref, is daar gesteun op basiese beskrywende statistiese gegewens ten einde verkennend te werk te gaan om te kan sê of opmerkings wel gebruik word. Die verspreiding van opmerkings binne die onderskeie tesisse self word ook vlugtig aangeraak. Uiteraard is dit nie moontlik om die resultate van die drie gevallestudies na die algemene populasie te veralgemeen nie. Verdere studies sal ook nodig wees om kommentaar te lewer oor die beduidendheid van die aantal opmerkings wat wel gebruik word.

Ten opsigte van die tweede navorsingsvraag word basiese beskrywende statistiese gegewens asook kwalitatiewe ontledings aangebied om 'n oorsig te gee van die soorte tekstuele probleme wat deur die opmerkings betrek word. Die statistiese beskrywing sowel as die kwalitatiewe ontleding berus op 'n raamwerk waarin vyf soorte tekstuele probleme onderskei word (sien afdeling 3.3). ${ }^{16}$ Voorts word daar gesteun op die EAC se riglyne vir die etiese hantering van die betrokke tekstuele probleme (sien ook afdeling 3.3) ten einde te probeer bepaal in watter mate redigeerders se hantering van verskillende tekstuele probleme met die internasionale riglyne strook. Dit is egter onbekend of die betrokke redigeerders wel met die EAC se riglyne vertroud is. Wanneer daar afleidings gemaak word oor die ooreenstemming tussen die redigeerders se aktiwiteite en die bestaande riglyne, word daar nie verwys na of die redigeerders die riglyne bewus navolg of nie. Dit gaan eerder oor die ooreenstemming tussen hulle onderskeie praktyke en die bestaande riglyne.

Om die derde navorsingsvraag te beantwoord, is die opmerkings almal eers kwalitatief bestudeer. Op grond van of die redigeerder self 'n besluit oor 'n bepaalde tekstuele probleem geneem het (al dan nie), is twee hoofkategorieë onderskei, wat verder in kleiner kategorieë verdeel is op grond van die taalhandeling in die opmerking. ${ }^{17}$ Daar word aanvaar dat om nie 'n besluit te neem nie, maar die student se eie betrokkenheid te stimuleer (deur byvoorbeeld 'n vraag te stel), op 'n bewustheid van die student se leerproses kan dui. Daarteenoor kan die verduideliking van 'n wysiging wat aangebring is ook die student se eie leer ten doel hê, maar dit kan ook 'n sigbaarmaking van die redigeerproses wees. Nietemin dui die blote aanbied van 'n opmerking op 'n bewustheid van kommunikasie met die student op metavlak, alhoewel die individuele opmerkings die prosesbenadering in wisselende mate kan weerspieël. Voorts is basiese beskrywende statistiese gegewens gebruik om 'n aanduiding te gee van die voorkoms van die onderskeie soorte opmerkings.

Die vierde navorsingsvraag is beantwoord deur hoofsaaklik ' $n$ kwalitatiewe ondersoek van die opmerkings self, maar ook deur terug te verwys na die bevindinge van navorsingsvraag 1, 2 en 3 .

\subsection{Teksseleksie}

Die bekombaarheid van geredigeerde tesisse plaas 'n definitiewe beperking op die studie deurdat slegs drie tesisse vir ontleding ingesamel kon word. Daar is spesifiek gesoek na tesisse wat meer as slegs 'n "ligte" redigering ondergaan het, bedoelende dat die teks op meer vlakke

\footnotetext{
${ }^{16}$ Die navorser het die verskillende opmerkings self in een (of meer) van die vyf kategorieë ingedeel. Uiteraard is hierdie werkswyse subjektief, en die ideaal sou wel wees dat die kategorisering deur 'n tweede navorser gekontroleer word. Die resultate moet dus teen hierdie agtergrond vertolk word.

${ }^{17}$ Ook in hierdie geval geld die opmerking wat in voetnoot 16 gegee is: Die indeling kan weer eens as subjektief beskou word en resultate moet in die lig hiervan geïnterpreteer word.
} 
as slegs die vlak van kopieredigering geredigeer is. ${ }^{18}$ Die uitvoer van 'n sogenaamde omvattende redigering ${ }^{19}$ is as kriterium vir insluiting gebruik; dus, redigering waartydens aspekte soos die volgende hanteer is:

- Kopieredigeringsaspekte

- Probleme met sins- en paragraafbou

- Stilistiese probleme (waaronder herhaling, vaagheid en dubbelsinnigheid)

- Opskrifte

- Verwysingstyl

- Interne verwysings soos kruisverwysings, bladsyverwysings, voet- en eindnootnommers en die inhoudsopgawe (Redigering van jou tesis of navorsingsverslag g.d.)

Die insluiting van die kriterium van 'n omvattende redigering het enersyds die voordeel dat die drie voorbeelde vergelykbaar is wat die omvang van die redigering betref. In 'n tesis wat slegs "lig" geredigeer is, sal byvoorbeeld herhaling nie uitgewys word nie en ook word stilistiese probleme op ' $n$ baie beperkte wyse hanteer, terwyl omvattende redigering hierdie probleme hanteer. Andersyds het dit implikasies vir die interpretasie van die resultate deurdat dit ook vooroordeel in die hand kan werk: tesisse wat omvattend geredigeer is, bevat moontlik meer kommentaar as tesisse wat "lig" geredigeer is, omdat die redigeerder met omvattende redigering die ruimte het om byvoorbeeld stilistiese probleme toe te lig. Dit is nodig dat die bevindinge teen hierdie agtergrond vertolk word.

'n Aantal privaat redigeerders (almal oud-US-studente) is gekontak met die oog op die verkryging van geredigeerde tesisse as data. Twee redigeerders kon elk een tesis voorsien wat voldoen aan die vereiste van "omvattende" redigering.

Die US Taaldiens is genader om tesisse te bekom wat deur medewerkers geredigeer is. Alhoewel die Taaldiens geredelik toestemming verleen het, moes die toestemming van die betrokke outeurs ook verkry word en 'n versoek is per e-pos aan die outeurs gerig. Slegs drie outeurs het gereageer en toestemming verleen. Eers hierna het die US Taaldiens die geredigeerde tesisse beskikbaar gestel en kon daar (1) vasgestel word wie die redigeerder was ${ }^{20}$ en (2) bepaal word of die tesis wel omvattend geredigeer is. Uiteindelik kon een voorbeeldteks van die US Taaldiens gebruik word.

Die geredigeerde tesisse is almal in Engels geskryf, maar verskil van mekaar wat betref die spesifieke kwalifikasie waarvoor die onderskeie studente die tesis ingedien het (hoewel al drie op magistervlak is) en die lengte daarvan:

\footnotetext{
${ }^{18}$ Kopieredigering verwys na die redigering van die teks op die sogenaamde mikrovlak, met ander woorde die korreksie van spel-, tik- en basiese grammatikale foute; die nagaan van interpunksie en die uitwys van ontoepaslike woordgebruik. Verwys hier na die US Taaldiens se dokument "Redigering van jou tesis of navorsingsverslag" (g.d.) waarin tussen "ligte" en "omvattende" redigering onderskei word - kopieredigering kan as "ligte" redigering beskou word.

${ }^{19}$ Sien die US Taaldiens se dokument "Redigering van jou tesis of navorsingsverslag" (g.d.) waarin die konsep "omvattende redigering" verduidelik word. Die aspekte wat vervolgens gelys word, is wat die US Taaldiens as 'n beskrywing van "omvattende redigering" beskou.

${ }^{20}$ Sodat daar nie twee tesisse ingesluit word wat deur dieselfde redigeerder hanteer is nie, met die doel om die drie voorbeelde ietwat meer verteenwoordigend te mak.
} 


\begin{tabular}{|l|l|l|l|}
\hline & Redigeerder & Graad waarvoor ingedien & Lengte $^{21}$ \\
\hline Tesis 1 & Privaat & $\begin{array}{l}\text { MIng (Elektriese en } \\
\text { Elektroniese Ingenieurswese), } \\
\text { US }\end{array}$ & $\begin{array}{l}\text { 68pp. } \\
\text { Bronnelys nie } \\
\text { geredigeer nie }\end{array}$ \\
\hline Tesis 2 & US Taaldiens ${ }^{22}$ & $\begin{array}{l}\text { MA (Sosiologie en Sosiale } \\
\text { Antropologie), US }\end{array}$ & $\begin{array}{l}\text { 91pp. } \\
\text { Bronnelys wel } \\
\text { geredigeer }\end{array}$ \\
\hline Tesis 3 & Privaat & MPhil (Vertaling), US & $\begin{array}{l}\text { 126pp. } \\
\text { Bronnelys wel } \\
\text { geredigeer }\end{array}$ \\
\hline
\end{tabular}

Tabel 1: Inligting oor die drie tesisse wat as gevallestudies gebruik is

Die studie is beperk deurdat dit slegs 'n eerste en verkennende ondersoek is wat veral ten doel het om 'n ondersoekterrein bloot te lê. Ook word die studie se geldigheid en veralgemeenbaarheid beperk deurdat slegs drie gevallestudies betrek word. Hiernaas plaas al drie redigeerders se bande met die US (hetsy oud-US-studente of 'n US-medewerker) ook 'n beperking op die veralgemeenbaarheid van die bevindinge vir die hele Suid-Afrikaanse konteks. Die agtergrond (met ander woorde opleiding en ervaring) van die redigeerders word voorts nie verreken nie. Die feit dat die redigeerders ook nie dieselfde opdrag (in terme van aspekte wat aangeraak moet word) ontvang het nie en daar slegs gesoek is na voorbeelde van "omvattende" redigering, lei daartoe dat die drie gevallestudies nie werklik wetenskaplik met mekaar vergelykbaar is nie - die vergelykings wat aangebied word, het eerder die doel om die terrein te karteer. Inferensiële statistiese ontledings is nie uitgevoer nie, omdat dit nie werklik hier aangedui is nie, gegee die feit dat slegs drie voorbeelde betrek is en ewekansige steekproefneming nie gebruik is nie.

\subsection{Data-ontleding: 'n raamwerk}

Ten einde die navorsingsvrae (veral vraag ii en iii) bevredigend te kan beantwoord, is dit nodig om op teoretiese vlak die volgende raamwerke vir ontleding aan die navorser te verskaf:

- Die soorte tekstuele probleme wat deur redigeerders hanteer kan word

- Riglyne rakende die soorte tekstuele probleme wat wel binne etiese akademiese redigering hanteer mag word

- Die verskillende soorte probleemoplossingsaktiwiteite wat redigeerders prakties kan toepas

Law (2011) se standaarde vir redigering onderskei duidelike soorte tekstuele probleme. Die stel standaarde wat sy voorstel bestaan uit twee afdelings, naamlik (1) tekstuele take vir redigeerders en (2) buitetekstuele vaardighede vir redigeerders:

\footnotetext{
${ }^{21}$ Aantal bladsye met spoorveranderinge; bronnelys ingesluit.

${ }^{22}$ Die redigeerwerk is ook nagesien deur 'n gehaltekontroleur van die US Taaldiens.
} 
1. Tekstuele take vir redigeerders
1.1 Kopieredigering
1.2 Stilistiese redigering
1.3 Strukturele redigering
1.4 Inhoudelike redigering
1.5 Proeflees

2. Buitetekstuele vaardighede vir redigeerders

2.1 Tegniese vaardighede en bedryfskennis

2.2 Persoonlike en interpersoonlike vaardighede

2.3 Gespesialiseerde kennis

(Law 2011:290)

Dit is egter nie duidelik hoe hierdie standaarde verband hou met die bestaande internasionale standaarde (naamlik van EAC en CASE) nie, en Law (2011) verwys ook nie in haar artikel na hierdie bestaande standaarde nie. Law se voorgestelde standaarde berus grootliks op die uiteensetting van die vier soorte redigering deur Mossop (2007), maar dit is onduidelik of die internasionale standaarde tydens die formulering van die voorgestelde standaarde betrek is. Daar is dus besluit om die internasionale standaarde vir algemene sowel as tesisredigering te ondersoek, alvorens enige teoretiese uiteensetting van die moontlike soorte tekstuele probleme aanvaar kan word.

In Australië bestaan die "Australian standards for editing practice" (CASE 2013) sowel as "Guidelines for editing research theses" (IPEd 2010). Albei dokumente sien die redigeertaak as bestaande uit verskeie standaarde, ${ }^{23}$ wat redelik maklik omgeskakel kan word in soorte tekstuele probleme waaraan redigeerders tydens die redigeerproses aandag kan gee. Dieselfde geld vir die Kanadese konteks waar sowel die "Professional editorial standards" (2009) as die "Guidelines for ethical editing of theses/dissertations" (2012) deur die Editors' Association of Canada (EAC) neergelê is. Ook die EAC se uiteensetting van verskeie standaarde erken die kompleksiteit van die redigeertaak en kan ook in spesifieke soorte tekstuele probleme omgeskakel word.

Volgens die "Australian standards for editing practice" (CASE 2013) word die volgende standaarde $^{24}$ vir redigering onderskei:

A. Professionele praktyk: professionele optrede, kommunikasie, die publikasieproses, regs- en etiese kwessies, ontwerpaspekte, hulpbronne en die drukproses

B. Bestuur en skakeling: projekomskrywing, projekdokumentasie, monitering

C. Inhoud en struktuur: akademiese inhoud, argument, makrostruktuur, volgorde van inhoud, struktuuraanduidings, verwysings

D. Taal en illustrasies: helderheid, toonaard, grammatika, taalgebruik, spelling, interpunksie, grafiese materiaal

E. Volledigheid en konsekwentheid: spelling, vorm en inhoud van voor- en agterwerk, akkuraatheid en volledigheid van kruisverwysings, konsekwente aanbiedingstyl wat betref lettertipe, opskrifte, konsekwentheid, akkuraatheid en volledigheid van verwysings

\footnotetext{
${ }^{23}$ IPEd (2010) volg CASE (2013) se indeling in verskillende standaarde.

24 "Standaarde" kan in hierdie besondere konteks ook vertolk word as dimensies, soorte of vlakke.
} 
Standaard A en B lê tegnies gesproke buite die domein van ware praktiese teksredigering, alhoewel dit verdienstelik is om ook hierdie aspekte as deel van die volledige redigeerproses te verreken. Vir die doel van hierdie studie word hulle egter verder buite rekening gelaat. Standaard C, D en E sou onderskeidelik omgeskakel kon word in die volgende soorte tekstuele probleme wat die redigeerder mag oplet en regstel: ${ }^{.25}$

C: Inhoudelike en strukturele kwessies

D: Taalkwessies en grafiese materiaal (waaronder illustrasies), maar ook tabelle en ander grafika

E: Volledigheid en konsekwentheid

IPEd (2010) gebruik, soos reeds genoem, CASE (2013) se standaarde as vertrekpunt en meld spesifiek dat slegs standaard D en E deur akademiese redigeerders hanteer behoort te word. Indien standaard C (inhoudelike en strukturele kwessies) ter sprake kom, mag slegs voorbeelde gegee word, alhoewel dit onduidelik is wat presies hier deur die outeurs van die dokument bedoel word - wat moet die "voorbeeld" behels en in watter mate moet dit verband hou met die onderhawige kwessie in die teks? Word daar dalk bedoel dat ' $n$ riglyn of advies eerder as 'n werklike "voorbeeld" gegee moet word? Wat hierdie punt betref, is IPEd se riglyne dus nog gebrekkig.

Alhoewel 'n standaardwerk oor redigering soos Butcher's copy-editing (2006) net soos CASE (2013) die aspekte van inhoud en struktuur onder 'n enkele soort redigering tuisbring, kan daar kritiek teen so 'n groepering ingebring word, omdat ware inhoudelike aspekte tog te skei is van die meer tegniese strukturele kwessies soos volgorde of struktuurmerkers (wat ook opskrifte kan insluit). Dit is voorts ook problematies dat korrekte taalgebruik en 'n stilistiese kwessie soos helderheid saamgegroepeer word onder standaard D; terselfdertyd is dit verwarrend dat verwysings as ' $n$ kategorie onder standaard $\mathrm{C}$ gegee word terwyl verwysings ook weer onder standaard E ter sprake kom (nou met spesifieke verwysing na die konsekwentheid, akkuraatheid en volledigheid daarvan). Alhoewel standaard E van die oorhoofse opskrif "volledigheid en konsekwentheid" voorsien word, is dit nie uit die standaarde self duidelik dat slegs hierdie twee kwessies daaronder ingesluit word nie.

Konsekwentheidskwessies word wel in redelike besonderhede aangebied, maar met volledigheid word klaarblyklik nie veel meer bedoel as om te sorg dat alle komponente van die teks in die manuskrip ingesluit is nie. Myns insiens sou hierdie kwessie gewoon onder inhoudelike kwessies aangestip kon word, eerder as om daaraan die status van 'n afsonderlike standaard of kategorie te verleen. Daarteenoor sou konsekwentheid wel bestaansreg as losstaande kategorie kon hê. Opsommend beskou is IPEd se aanbieding van die standaarde redelik rigied, gegee die saampersing van redelik uiteenlopende aspekte (byvoorbeeld taalkwessies en grafiese materiaal) in een standaard. Ook is die perspektief baie beperkend ten opsigte van die skrywer-student se akademiese ontwikkeling, en dit blyk 'n volkome produkgeoriënteerde benadering te weerspieël.

Die EAC se "Professional editorial standards" (2009) bied myns insiens 'n meer genuanseerde indeling met hulle uiteensetting van die redigeertaak as bestaande uit die volgende vyf standaarde:

\footnotetext{
${ }^{25}$ Teen die agtergrond van Mossop (2007) en Law (2011).
} 

A. Die grondslae van redigering
B. Strukturele redigering
C. Stilistiese redigering
D. Kopieredigering
E. Proeflees

Die omskakeling van hierdie standaarde in soorte tekstuele kwessies vir die redigeerder se aandag, is in hierdie geval makliker. Standaard A hanteer, soos CASE se standaard A en B, weer eens kwessies wat werklike teksredigering voorafgaan of bepaal, soos byvoorbeeld kennis van die publikasie-, ontwerp- en produksieproses. Standaard B, C en D stem egter ooreen met 'n outeur soos Mossop (2007) se baie pragmatiese indeling van redigering in vier soorte, te wete inhoudelike, strukturele, stilistiese en kopieredigering, alhoewel dit opmerklik is dat inhoudelike redigering as hoofkategorie deur die EAC weggelaat word. Wanneer die standaarde egter van nader beskou word, blyk dit dat inhoudelike kwessies (o.m. standaard B5: byvoegings en weglatings) onder standaard B (strukturele redigering) tuisgebring word. Dit kan egter verwarrend wees, en in hierdie geval is Mossop se onderskeid tussen inhoudelike en strukturele redigering verkieslik. Daar sou ook geargumenteer kon word dat proeflees onder kopieredigering inbegrepe is, en dat die onderskeid eerder relevant is vir byvoorbeeld die publikasieproses in 'n groot uitgewery. Tydens akademiese redigering geskied proeflees as deel van die kopieredigering van die teks.

"Guidelines for ethical editing of theses/dissertations" (EAC 2012) se boodskap oor die reikwydte van akademiese redigering is egter duidelik: "Editing must never affect the content or structure of the student's thesis." Hiervolgens is wysigings wat verder strek as die korreksie van grammatika, idioom, interpunksie, spelling en tegniese aspekte ontoelaatbaar. Nietemin is die EAC se model nie so rigied as wat hierdie voorskrif voorgee nie. Die genoemde dokument maak in werklikheid ruim voorsiening vir die gebruik van opmerkings ${ }^{26}$ wanneer die redigeerder van mening is dat verbeteringe ten opsigte van die volgende kwessies aangedui is: ${ }^{27}$

- Strukturele redigering

- B5 Weglatings, byvoegings

- B6 Korrektheid van gegewens, voldoende navorsing, inhoudelike balans

- B7 Formaat - byvoorbeeld die aanbied van gewone teks met baie syfers in die vorm van 'n tabel

- Stilistiese redigering

- Helderheid

- C1 Sinskonstruksie

- C2 Woordkeuse

- C3 Herskryf van sinne, paragrawe en teksgedeeltes

- C4 Verstaanbaar maak van tekselemente

- C5 Tabelle en ander grafiese elemente

\footnotetext{
26 "Opmerkings" word hier generies bedoel en verwys nie spesifiek na die gebruik van die funksie in MS Word nie, alhoewel hierdie funksie met vrug benut kan word.

${ }^{27}$ Die kwessies word benoem soos in die oorspronklike dokument - vandaar die kodes (bv. B5 of C1) wat elk op 'n bepaalde (sub)standaard van redigering dui.
} 
- Stilistiese redigering

- Vloei

- C6 Oorgange tussen sinne en paragrawe

- C7 Interne struktuur van paragrawe - volgorde van sinne

- C8 Lengte en struktuur van paragrawe

- Taal

- C9 Lengte en struktuur van sinne

- C12 Bondigheid

- Kopieredigering

- D8 Inkonsekwenthede wat betref logika, feite, kruisverwysings

- D11 Akkuraatheid: name, titels, aanhalings, webskakels

- D12 Akkuraatheid: wiskundige en statistiese gegewens

- D13 Volledigheid: opskrifte, webskakels

- D14 Ontbrekende verwysings

- Proeflees

- E7 Tipografiese foute en probleme wat formaat betref

- E8 Konsekwentheid en akkuraatheid van elemente soos kruisverwysings en titels

- E13 Inkonsekwenthede: spelling, interpunksie, feite

- E14 Inkorporeer wysigings deur outeur en ander individue - dui aan indien teenstrydig

(EAC 2012)

Wat betref die gestelde behoefte aan 'n model wat rekenskap gee van (1) soorte tekstuele probleme wat deur redigeerders hanteer kan word en (2) riglyne oor die soorte tekstuele probleme wat wel binne etiese akademiese redigering hanteer mag word, word daar dus voorgestel dat die EAC se standaarde, eerder as dié van CASE, as vertrekpunt gebruik word. Eersgenoemde standaarde is buigsaam genoeg om die prosesbenadering te akkommodeer, maar tog bied dit riglyne in terme van waar die grense van etiese akademiese redigering lê.

'n Punt van kritiek is wel dat die EAC inhoudelike kwessies (standaard B5-B11) onder strukturele redigering insluit. Kleiner punte van kritiek is dat sommige aspekte van akademiese skryfwerk en redigering nie in die model genoem word nie - 'n akademiese teks se opskrifstruktuur as deel van die teks se eksterne struktuur word byvoorbeeld nie deur die EAC se standaarde verreken nie. Konsekwentheid word ook problematies hanteer deurdat dit onder proeflees en kopieredigering ingesluit word; daarnaas kan die insluiting van inhoudelike konsekwentheid asook die insluiting van verwysings onder kopieredigering bevraagteken word. Op grond van hierdie kritiek word voorgestel dat konsekwentheid as 'n afsonderlike soort kwessie in 'n model ingesluit word, in navolging van Butcher (2006:2) wat "[c]hecking for consistency" as een van vier soorte redigering onderskei. Daar word voorts voorgestel dat die hantering van verwysings onder inhoudelike redigering sowel as kopieredigering ingesluit word - die aanwesigheid (al dan nie) van 'n verwysing word onder inhoudelike redigering geklassifiseer, terwyl die versorging van die formaat daarvan onder kopieredigering geklassifiseer word. 
Met hierdie aspekte in gedagte word die volgende raamwerk voorgestel as grondslag vir die ontleding van soorte tekstuele veranderinge tydens die redigeertaak:

1. Inhoudelike kwessies (ook aanwesigheid van verwysings; kan ook etiese kwessies insluit, waaronder plagiaat)

2. Strukturele kwessies

3. Stilistiese kwessies

4. Kwessies wat verband hou met kopieredigering (sluit proefleeskwessies in, asook die formaat van verwysings in akademiese tekste)

5. Kwessies wat verband hou met konsekwentheid

Daar is besluit om kwessies ten opsigte van grafiese materiaal in ooreenstemming met sowel Mossop (2007) as Butcher (2006) se indelings nie in die raamwerk in te sluit nie. Die fokus is derhalwe op talige kwessies.

Wat riglyne oor die etiese redigering van akademiese tekste betref, word die EAC se gedetailleerde uiteensetting (hierbo gegee) vir die doel van die huidige studie aanvaar.

Ten opsigte van die behoefte aan 'n raamwerk aan die hand waarvan kategorieë van probleemoplossingsaktiwiteite beskryf kan word, word Hill (2011) se uiteensetting as vertrekpunt geneem. Volgens hom word die volgende vyf aktiwiteite raakgesien tydens redigeerders se werklike hantering van tekstuele probleme:

1. Korreksie sonder enige kommentaar

2. Korreksie gevolg deur 'n verduideliking wat die wysiging verduidelik/motiveer

3. Oplossing of alternatiewe oplossings

4. Verduideliking waarom die betrokke aspek problematies is en instruksie aan die skrywer om die korreksie aan te bring

5. Behoud van die betrokke tekstuele element

Soos egter uit die praktiese ontleding blyk, is Hill se uiteensetting beperk deurdat daar in die drie bestudeerde gevalle 'n groter verskeidenheid aktiwiteite waargeneem is. Soos later aangetoon word, is daar deskriptief te werk gegaan waarvolgens eers twee hoofkategorieë en daarna elf kleiner kategorieë geïdentifiseer is.

\section{Resultate}

\subsection{Navorsingsvraag 1}

$\mathrm{Na}$ aanleiding van die eerste navorsingsvraag ("word opmerkings met behulp van MS Word deur die redigeerders van tesisse en/of proefskrifte benut?") is die aantal opmerkings per tesis en per hoofstuk nagegaan. Die resultate word in tabel 2 asook figuur 1 opgesom: 


\begin{tabular}{|c|c|c|c|c|c|c|c|}
\hline Tesis & $\begin{array}{l}\text { Totale aantal } \\
\text { opmerkings } \\
\text { vir tesis }{ }^{28}\end{array}$ & $\begin{array}{l}\text { Hoofstuk } \\
1\end{array}$ & $\begin{array}{l}\text { Hoofstuk } \\
2\end{array}$ & $\begin{array}{l}\text { Hoofstuk } \\
3\end{array}$ & $\begin{array}{l}\text { Hoofstuk } \\
4\end{array}$ & $\begin{array}{l}\text { Hoofstuk } \\
5\end{array}$ & $\begin{array}{l}\text { Hoofstuk } \\
6^{29}\end{array}$ \\
\hline $\begin{array}{l}\text { Tesis } 1 \\
\text { (15 } 377 \text { woorde } \\
\text { sonder hfst. 4) }\end{array}$ & 51 & $\begin{array}{l}13 \\
(1833 \\
\text { woorde })^{30}\end{array}$ & $\begin{array}{l}20 \\
(6519 \\
\text { woorde) }\end{array}$ & $\begin{array}{l}9 \\
(5462 \\
\text { woorde })\end{array}$ & $\begin{array}{l}\text { Nie } \\
\text { geredigeer } \\
\text { nie }^{31}\end{array}$ & $\begin{array}{l}8 \\
(1563 \\
\text { woorde) }\end{array}$ & - \\
\hline $\begin{array}{l}\text { Gemiddeld per } \\
300 \text { woorde }^{32}\end{array}$ & $\mathbf{1 , 0 0}$ & 2,13 & 0,92 & 0,49 & - & 1,54 & - \\
\hline $\begin{array}{l}\text { Tesis } 2 \\
\text { (26893 } \\
\text { woorde) }\end{array}$ & 182 & $\begin{array}{l}30^{33} \\
(2848 \\
\text { woorde) }\end{array}$ & $\begin{array}{l}78^{34} \\
(7819 \\
\text { woorde) }\end{array}$ & $\begin{array}{l}47 \\
(5343 \\
\text { woorde) }\end{array}$ & $\begin{array}{l}9 \\
(2483 \\
\text { woorde) }\end{array}$ & $\begin{array}{l}8 \\
(5664 \\
\text { woorde })\end{array}$ & $\begin{array}{l}10 \\
(2736 \\
\text { woorde })\end{array}$ \\
\hline $\begin{array}{l}\text { Gemiddeld per } \\
300 \text { woorde }\end{array}$ & 1,91 & 3,16 & 3,00 & 2,64 & 1,09 & 0,42 & 1,1 \\
\hline $\begin{array}{l}\text { Tesis } 3 \\
\text { (39 994 } \\
\text { woorde) }\end{array}$ & 32 & $\begin{array}{l}10 \\
(3824 \\
\text { woorde) }\end{array}$ & $\begin{array}{l}8 \\
(8901 \\
\text { woorde })\end{array}$ & $\begin{array}{l}6 \\
(7948 \\
\text { woorde) }\end{array}$ & $\begin{array}{l}4 \\
(8233 \\
\text { woorde) }\end{array}$ & $\begin{array}{l}4 \\
(11088 \\
\text { woorde })\end{array}$ & - \\
\hline $\begin{array}{l}\text { Gemiddeld per } \\
300 \text { woorde }\end{array}$ & 0,24 & 0,78 & 0,27 & 0,27 & 0,15 & 0,11 & - \\
\hline
\end{tabular}

Tabel 2: Opmerkings per tesis en per hoofstuk

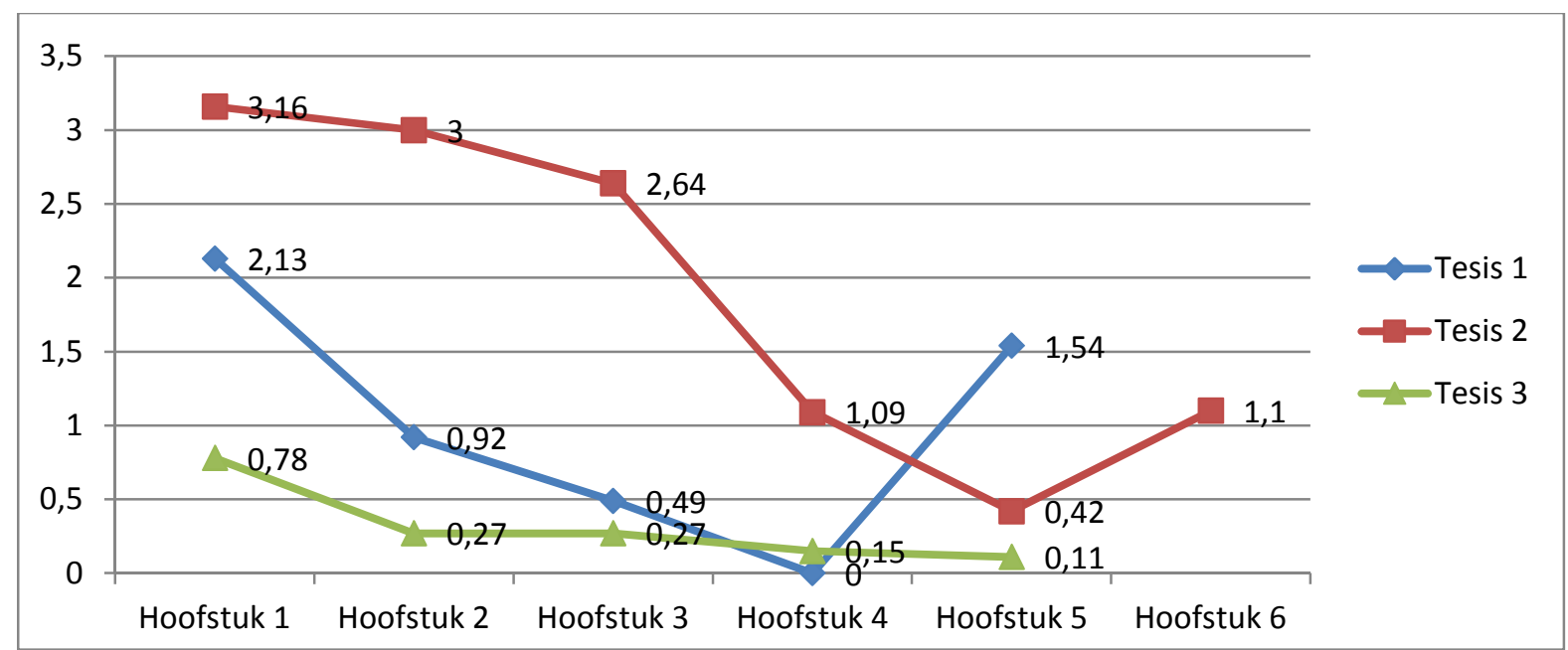

Figuur 1: Tesis 1, 2 en 3 - gemiddelde aantal opmerkings per 300 woorde en volgens hoofstuk

\footnotetext{
${ }^{28}$ Telkens sonder die bronnelys bereken.

${ }^{29}$ Slegs tesis 2 het ses hoofstukke.

${ }^{30}$ Woordtelling is telkens vir die geredigeerde weergawe.

${ }^{31}$ Die vierde hoofstuk bevat hoofsaaklik die besonderhede oor en resultate van toetse en metings. Dit bevat min teks en is op versoek van die student nie geredigeer nie. Die hoofstuk is gevolglik nie ingesluit in die ontledings nie.

${ }^{32}$ Daar is besluit om die gemiddelde aantal opmerkings per 300 woorde te bereken, aangesien 300 woorde naastenby een bladsy teks verteenwoordig, maar 'n meer gestandaardiseerde maatstaf as bloot 'n bladsy verskaf. ${ }^{33}$ Die redigering is ter wille van gehaltebeheer deur ' $n$ kontroleur van die US Taaldiens nagesien, wat in hoofstuk 15 opmerkings ingevoeg het naas die 25 deur die redigeerder.

${ }^{34}$ Die kontroleur het 1 opmerking in hoofstuk 2 ingevoeg naas die 77 deur die redigeerder.
} 
Die resultate dui aan dat opmerkings wel in al die tesisse gebruik is, en ook in al die hoofstukke wat geredigeer is. Ongeag die inhoud van die opmerkings, kan hierdie bevinding vertolk word as dat die redigeerder wel met die student oor die skryf- en/of redigeerproses kommunikeer.

Alhoewel die resultate nie statisties verwerk is om inligting oor die beduidendheid daarvan te gee nie, is dit nietemin opmerklik dat die routellings vir die eerste hoofstuk van al drie tesisse redelik hoog is, vergeleke met van die ander hoofstukke. Een moontlike rede hiervoor kan wees dat die eerste hoofstuk van 'n tesis allerweë as besonder belangrik beskou word (synde 'n "eerste indruk") en dat redigeerders dus moontlik dienooreenkomstig besondere aandag aan hierdie hoofstuk bestee. 'n Ander moontlike - en selfs meer waarskynlike - rede kan wees dat redigeerders foute/probleme wat deurgaans voorkom reeds tydens die eerste verskyning daarvan aandui en byvoorbeeld verduidelik waarom dit ' $n$ fout/probleem is. Later in die tesis aanvaar die redigeerder dus moontlik dat die kwessie reeds toegelig is. Dit is ook interessant om te let op die groter aantal opmerkings in die laaste hoofstuk van tesis 1 en 2, terwyl die telling vir tesis 3 in vergelyking daarmee laer is. Oor redes hiervoor kan gespekuleer word: die redigeerder van tesis 1 beskou die slothoofstuk moontlik ook as 'n sleutelhoofstuk in 'n tesis.

Verdere studies met 'n groter steekproef sou kon aandui of die tendens om meer opmerkings in die eerste hoofstuk te gebruik, wel beduidend is; ook kan daar vasgestel word of daar enigsins 'n tendens is om ook in die laaste hoofstuk meer opmerkings te gebruik. Voorts sou daar ondersoek ingestel kon word na die effek wat veranderlikes soos die vakgebied en die redigeerder se opleiding en/of ondervinding op die frekwensie en verspreiding van die opmerkings het.

\subsection{Navorsingsvraag 2}

Die tweede navorsingsvraag behels die soorte tekstuele probleme wat deur die opmerkings betrek word, en in watter mate die waargenome opmerkings met internasionale riglyne in hierdie verband strook. Met die oog op die uiteindelike aanbieding van 'n gevolgtrekking, betrek die bespreking reeds die kwessie van of ' $n$ produk- of ' $n$ prosesbenadering deur die voorbeelde geïmpliseer word.

Tabel 3 en figuur 2 en 3 som die resultate van die basiese beskrywende statistiese ondersoek op: 


\begin{tabular}{|c|c|c|c|c|c|c|}
\hline $\begin{array}{l}\text { Tekstuele } \\
\text { kategorie }\end{array}$ & Inhoudelik & Struktureel & Stilisties & Kopieredigering & Konsekwentheid & Totaal \\
\hline Tesis 1 & $\begin{array}{l}9^{35} \\
16,07 \%\end{array}$ & $\begin{array}{l}8^{36} \\
14,29 \%\end{array}$ & $\begin{array}{l}5 \\
8,93 \%\end{array}$ & $\begin{array}{l}30^{37} \\
\mathbf{5 3 , 5 7 \%}\end{array}$ & $\begin{array}{l}4^{38} \\
\mathbf{7 , 1 4 \%}\end{array}$ & $56^{39}$ \\
\hline Tesis 2 & $\begin{array}{l}80 \\
\mathbf{4 3 , 9 5 \%}\end{array}$ & $\begin{array}{l}6 \\
\mathbf{3 , 3 0} \%\end{array}$ & $\begin{array}{l}2 \\
1,10 \%\end{array}$ & $\begin{array}{l}94 \\
51,65 \%\end{array}$ & $\begin{array}{l}0 \\
0 \%\end{array}$ & 182 \\
\hline Tesis 3 & $\begin{array}{l}14^{40} \\
\mathbf{4 1}, \mathbf{1 8} \%\end{array}$ & $\begin{array}{l}3 \\
8,82 \%\end{array}$ & $\begin{array}{l}9^{41} \\
\mathbf{2 6 , 4 7 \%}\end{array}$ & $\begin{array}{l}8 \\
23,53 \%\end{array}$ & $\begin{array}{l}0 \\
0 \%\end{array}$ & $34^{42}$ \\
\hline Totaal & $\begin{array}{l}103 \\
\mathbf{3 7 , 8 7 \%}\end{array}$ & $\begin{array}{l}17 \\
\mathbf{6 , 2 5 \%}\end{array}$ & $\begin{array}{l}16 \\
\mathbf{5 , 8 8 \%}\end{array}$ & $\begin{array}{l}132 \\
\mathbf{4 8 , 5 3 \%}\end{array}$ & $\begin{array}{l}4 \\
1,47 \%\end{array}$ & $272^{43}$ \\
\hline
\end{tabular}

Tabel 3: Soorte tekstuele probleme in opmerkings betrek

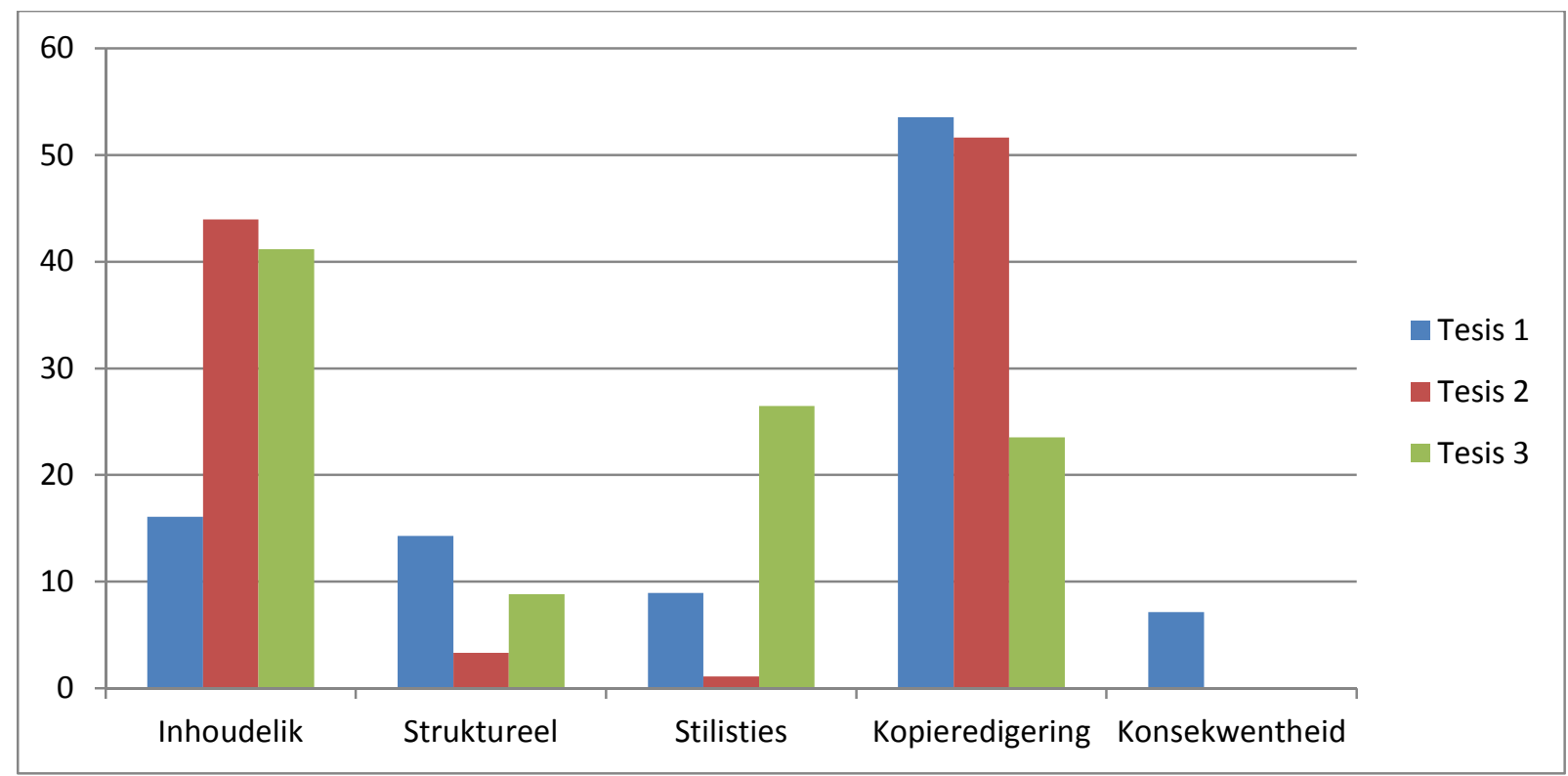

Figuur 2: Soorte tekstuele probleme in opmerkings betrek - per tesis

\footnotetext{
${ }^{35}$ Een van hierdie opmerkings kan ook geïnterpreteer word as om na 'n strukturele probleem te verwys.

${ }^{36}$ Een van hierdie opmerkings kan ook geïnterpreteer word as om na 'n inhoudelike probleem te verwys.

${ }^{37}$ Vier van hierdie opmerkings kan ook geïnterpreteer word as om na 'n konsekwentheidsprobleem te verwys.

${ }^{38}$ Vier van hierdie opmerkings kan ook geïnterpreteer word as om na 'n kopieredigeringsprobleem te verwys.

${ }^{39}$ Die totaal vir tesis 1 is dus hier 56 in plaas van 51, omdat vyf opmerkings almal na probleme op twee vlakke verwys en dus twee keer getel is.

${ }^{40}$ Twee van hierdie opmerkings kan ook geïnterpreteer word as om na 'n stilistiese probleem te verwys.

${ }^{41}$ Twee van hierdie opmerkings kan ook geïnterpreteer word as om na 'n inhoudelike probleem te verwys.

${ }^{42}$ Die totaal vir tesis 3 is dus hier 34 in plaas van 32, omdat twee opmerkings na probleme op twee vlakke verwys en dus twee keer getel is.

${ }^{43}$ Sien voetnote 40 en 43 vir die totaal van 272 in plaas van 265.
} 


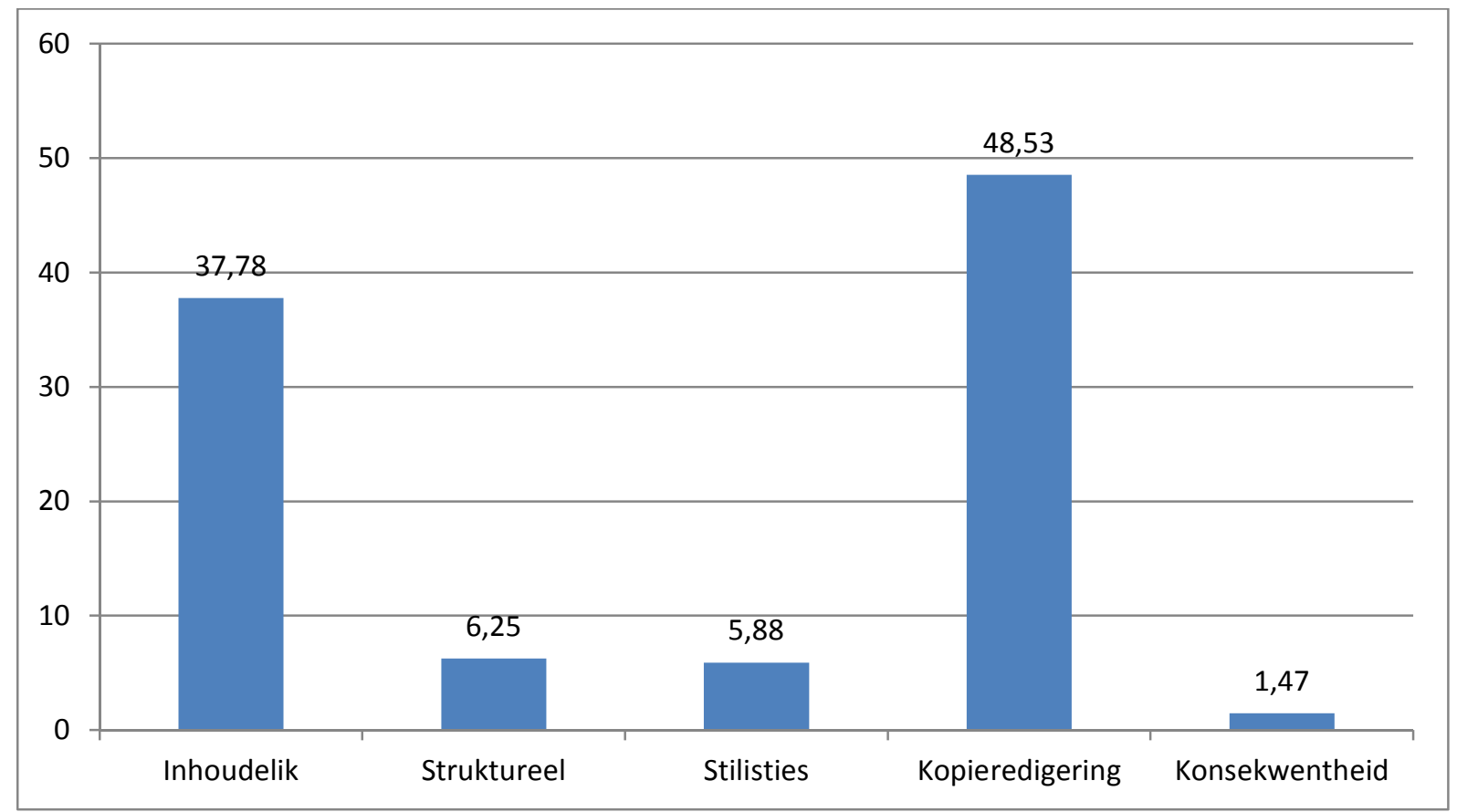

Figuur 3: Totale - soorte tekstuele probleme in opmerkings betrek

Uit tabel 3 asook figuur 2 blyk dit dat opmerkings met betrekking tot al vyf soorte tekstuele probleme in tesis 1 aangebied is. Die kategorie van kopieredigering toon die meeste opmerkings $(53,57 \%)$. Die student het heelwat foute gemaak, veral wat grammatika betref; ook was daar heelwat foute wat met tipografie verband hou en wat as deel van kopieredigering gereken is. Alhoewel opmerkings oor hierdie foute nie werklik nodig was nie en die redigeerder dit bloot sou kon wysig sonder enige opmerkings, het die redigeerder dit kennelik goedgedink om die student van sulke foute bewus te maak - vergelyk byvoorbeeld: "Hierdie" ${ }^{44}$ (sic) moet ook in die middel staan ter wille van konsekwentheid" (dus 'n opmerking wat met tipografie verband hou, maar ook die vlak van konsekwentheid betrek). Elders let die redigeerder op dat 'n gedeelte liefs in die verlede tyd aangebied moet word, maar verander dit nie en maak slegs die volgende opmerking: "Moet hierdie opsomming nie dalk [...] in die past tense (sic) wees nie? Die toetse is mos reeds uitgevoer." ${ }^{45}$ Deur slegs te bevraagteken eerder as slegs te wysig, spreek 'n duidelike bewustheid van die student se leerproses, oftewel 'n prosesbenadering.

Inhoudelike $(16,07 \%)$ en strukturele $(14,29 \%)$ kwessies is onderskeidelik die tweede en die derde meeste hanteer. Met verwysing na die inhoudelike vlak wys die redigeerder byvoorbeeld uit dat 'n slotparagraaf ontbreek (Tesis1:7), ${ }^{46}$ ooreenkomstig standaard B5. Die redigeerder oorskry wel enkele kere die grense soos deur die EAC gestel, soos wanneer die student op 'n denkfout gewys word (Tesis 1:9), maar die redigeerder dan 'n oplossing aanbied. Volgens die EAC se riglyne laat hierdie ingreep te min ruimte vir die student om self oor die probleem na te dink en dit op te los. Elders slaag die redigeerder wel daarin om binne die riglyne te werk wanneer 'n probleem ten opsigte van die student se argumentasie verduidelik word (Tesis 1:32), maar die student slegs gevra word om die gedeelte in heroënskou te neem, eerder as wat 'n oplossing voorgestel word. Eersgenoemde en laasgenoemde aktiwiteite kan as

\footnotetext{
${ }^{44}$ Die redigeerder bedoel "[h]ierdie vergelyking".

${ }^{45}$ Die redigeerder het oorwegend in Afrikaans met die student - albei se eerste taal - gekommunikeer.

${ }^{46}$ Die bladsynommer(s) in die betrokke voorbeeldtesis word telkens in hierdie formaat gegee.
} 
verteenwoordigend van die prosesbenadering beskou word, terwyl die aanbied van 'n oplossing meer na die produkbenadering op die kontinuum van opmerkings neig.

Op die vlak van struktuur vra die redigeerder in 'n opmerking: "Hoe vloei hierdie (sic) uit die vorige paragraaf?" en dui dan aan dat 'n verbindingsin nodig is, alhoewel die oplossing nie verskaf word nie (Tesis 1:64). Volgens die EAC se standaarde kan hierdie opmerking as verteenwoordigend van die stilistiese standaard C6 (oorgange tussen sinne en paragrawe) beskou word, alhoewel dit myns insiens veel eerder 'n strukturele kwessie aanraak. Nietemin tree die redigeerder in ooreenstemming met die riglyne op deur slegs 'n opmerking in te voeg, waaruit 'n prosesbenadering weer eens blyk.

Die minste opmerkings word ten opsigte van styl $(8,93 \%)$ en konsekwentheid $(7,14 \%)$ aangetref. Die student word byvoorbeeld gewys op die konsekwente toepassing van sekere keuses en die ruimte gelaat om self 'n keuse uit te oefen, alhoewel dit volgens die EAC se standaarde nie nodig is nie. Vergelyk in hierdie verband: "Soms gebruik jy real time [sonder koppelteken] en soms real-time [met koppelteken]. Ek maak dit nou oral met 'n koppelteken, maar jy kan gaan kyk of jy dit anders verkies." (Tesis 1:20). Ook hieruit blyk 'n ingesteldheid wat die student se refleksie oor en eienaarskap van sy werk wil stimuleer.

Elders word 'n vraag gestel om die student bewus te maak van die dikwels problematiese aard van die eerste persoon, veral in sekere natuurwetenskaplike omgewings: "Mag jy 'our' en 'I', ens. gebruik?" (Tesis 1:25). Alhoewel die dikwels kontensieuse kwessie van die eerste persoon teenoor die derde persoon volgens outeurs soos Du Toit en Smith-Müller (2003:86) onder styl tuishoort, word dit nie spesifiek in die EAC se standaarde gemeld nie. Die EAC se riglyne oor styl verwys wel na die keuse tussen die aktief- en passiefvorm (wat met die gebruik van die eerste en derde persoon verband hou, soos Du Toit en Smith-Müller [2003:86] verduidelik), maar daar is geen spesifieke verwysing na die hantering van die kwessie van die eerste teenoor die derde persoon nie. Daar word dus aanbeveel dat hierdie kwessie spesifiek in die riglyne ingesluit word - nie om die gebruik van enige opsie af te keur nie, maar eerder om redigeerders aan te raai om te evalueer of die tekstuele keuse binne die konteks van die teks gepas is. Deurdat die redigeerder die student wel hier bewus maak daarvan dat sommige akademiese omgewings die gebruik van die eerste persoon afkeur, word 'n prosesgerigte benadering weerspieël wat ten doel het dat die student krities oor sy/haar eie keuses sal nadink.

In tesis 2 is opmerkings nie ten opsigte van al die soorte tekstuele probleme aangebied nie daar is byvoorbeeld geen opmerkings ten opsigte van konsekwentheid nie, wat moontlik op 'n produkbenadering kan dui, sou dit met byvoorbeeld tesis 1 se $7,14 \%$ vergelyk word (sien figuur $2)$. Ook ten opsigte van styl $(1,1 \%)$ en struktuur $(3,3 \%)$ is daar min opmerkings, alhoewel die voorbeelde daarvan wel van 'n prosesbenadering getuig. Die student word byvoorbeeld gevra om ' $\mathrm{n}$ sin te herformuleer ("This is not clear. Please rephrase." - Tesis 2:32) wat in ooreenstemming met die EAC se riglyne (standaard C3) is. 'n Verdere probleem op stilistiese vlak word deur middel van 'n vraag hanteer, sodat die student self oor die betekenis van die woord moet nadink: "Would 'stationery' perhaps be more appropriate?" (Tesis 2:80). Dit is eweneens in ooreenstemming met die EA se riglyne. Hierdie twee voorbeelde spreek van 'n prosesbenadering waar die student self werk om sy/haar skryfwerk te verbeter.

Op die vlak van struktuur is die opmerkings beperk tot opskrifte (eksterne struktuur), soos die volgende voorbeeld aandui: "Do you agree with the numbering of the headings in this section? 
Family and community of origin, The school system and Financial factors are part of the Socioeconomic factors and Self-motivation is a different level heading then" (Tesis 2:46). ${ }^{47}$ Hier het die redigeerder 'n strukturele wysiging aangebring, maar versoek dat die student dit krities oorweeg. Opskrifte as 'n aspek van eksterne struktuur word nie in die EAC se riglyne verreken nie, soos reeds in afdeling 6 genoem, en dit is dus nie moontlik om kommentaar te lewer oor die navolging van die riglyne nie. Nietemin dui die direkte interaksie met die student op 'n prosesbenadering.

Inhoudelike aspekte ontvang die tweede meeste aandag in die opmerkings (43,95\%), en 'n nadere ontleding toon aan dat dit veral ontbrekende verwysings in hierdie kategorie is wat vir die hoë telling verantwoordelik is. ${ }^{48}$ Indien die EAC se kategorisering van verwysings wel as vertrekpunt geneem word, kan daar gesê word dat hierdie aspek korrek volgens die betrokke standaard (D14) hanteer word. Daar word egter voorgestel dat toekomstige standaarde vir SuidAfrika onderskei tussen die aanwesigheid van 'n verwysing ('n inhoudelike kwessie) en die formaat daarvan ('n kopieredigeringskwessie).

Dit is wel interessant dat sewe van die tien opmerkings in die laaste hoofstuk van tesis 2 met inhoudelike kwessies te make het. Wanneer die student na "poor black and African senior students" verwys, maak die redigeerder die opmerking: "Weren't most of them coloured? What is the difference between black and African? I would suggest you clarify how you make these distinctions somewhere early in your text, since it could be confusing to the reader if it is not clearly set out." (Tesis 2:82). Hierdie vraag word weer teen die einde van die hoofstuk herhaal, wanneer die redigeerder vra: "But what is the difference between African and black?" (Tesis 2:91). Deurdat die opmerking op inhoudelike verfyning afgestem is, oorskry die redigeerder die grense soos deur die EAC gestel. Hierdie soort vrae behoort eerder deur die studieleier gestel te word. Elders maak die redigeerder die volgende opmerking: "Tinto mentions more variables - shouldn't you mention them all? (Tesis 2:84). Hierdie opmerking behoort eweneens tot die domein van die studieleier. Daar kan wel afgelei word dat die opmerkings 'n prosesbenadering weerspieël, omdat hulle refleksie deur die student ten doel het.

In die res van die tesis (hoofstuk 1 tot 5) is daar egter min opmerkings wat met "ware" inhoudelike kwessies verband hou (slegs 60 uit 73) - die meeste van die opmerkings in hierdie kategorie het met verwysings te make. Die student is byvoorbeeld wel gevra om verbandhoudende begrippe toe te lig (Tesis 2:3), die geldigheid van 'n argument is bevraagteken (Tesis 2:37) en ontbrekende inligting word uitgewys (Tesis 2:52). Al hierdie aktiwiteite is in ooreenstemming met standaard B5 en dui op ' $\mathrm{n}$ prosesgerigte benadering.

Opmerkings wat verband hou met kopieredigering is die beste verteenwoordig $(54,07 \%)$. Die student het heelwat foute gemaak wat betref die formaat van die verwysings (wat vir die doel van die ondersoek as kopieredigering gereken is), en baie van die opmerkings in hierdie kategorie hou by nadere ondersoek verband met hierdie soort foute. By 'n gebrek aan leiding deur die EAC in hierdie verband, kan CASE se riglyne geraadpleeg word, wat die formaat van verwysings onder standaard E2.5 insluit. Hierdie soort foute mag volgens CASE sonder enige opmerkings gekorrigeer word, sodat die insluiting van heelwat opmerkings spesifiek op 'n

\footnotetext{
${ }^{47}$ Die kommentaar in tesis 2 is deurgaans in Engels. Engels is die student se eerste taal, terwyl die redigeerder se eerste taal Afrikaans is.

${ }^{48}$ Alhoewel die EAC se riglyne die insluiting van verwysings as 'n aspek van kopieredigering beskou, word dit vir die doeleindes van hierdie ondersoek as 'n inhoudelike kwessie hanteer.
} 
prosesbenadering dui. Die student word meermale herinner om bepaalde beginsels rakende verwysings korrek toe te pas, byvoorbeeld: "Use ${ }^{49}$ all the authors the first time" (Tesis 2:24, $41,44,48,50)$ - kennelik met die oog op die vaslegging van die beginsel by die student.

Hierdie prosesgerigtheid word ook weerspieël in ander opmerkings op die vlak van kopieredigering wat die student se betrokkenheid by die versorging van die teks ten doel het. $\mathrm{Na}$ aanleiding van ontbrekende aanhalingstekens ('n herhalende fout), vra die redigeerder byvoorbeeld: "Does the quotation end here?" (Tesis 2:63) en "Where does the quotation begin?" (Tesis 2:63). Daar word byvoorbeeld ook 'n opmerking ingevoeg om die student daarop attent te maak dat ' $n$ interne verwysing na 'n daaropvolgende afdeling ingevoeg moet word (Tesis 2:4), wat volgens die EAC se standaarde onder D13 (volledigheid) tuisgebring sou kon word.

Ook in tesis 3 is daar nie opmerkings ten opsigte van al die soorte tekstuele probleme nie (sien tabel 3 en figuur 2). Soos by tesis 2 is opmerkings ten opsigte van konsekwentheid afwesig, wat weer eens op 'n produkbenadering kan dui.

Die opmerkings in tesis 3 word deur inhoudelike kwessies oorheers $(41,18 \%)$. In enkele van die gevalle oorskry die redigeerder die gestelde grense van etiese redigering, byvoorbeeld wanneer die redigeerder ontbrekende inligting byvoeg en die student vervolgens vra om die byvoeging slegs goed te keur: "This description did not make sense. Please check that the info I imported is correct" (my kursivering) (Tesis 3:85). ${ }^{50}$ Hier is duidelik sprake daarvan dat die redigeerder verder gaan as wat die EAC se riglyne voorstel (die dokument noem juis eksplisiet dat geen nuwe inhoud bygevoeg mag word nie [EAC 2012:2]). So 'n wysiging kan gesien word as eerder verteenwoordigend van die produkbenadering, omdat die student nie noodwendig op 'n vlak van betekenisvolle leer by die kwessie gaan betrokke raak nie - die student kan dit bloot aanvaar sonder om daaroor na te dink. Daar kan egter ook geargumenteer word dat die student wel die wysiging kan oorweeg en daaruit leer, sodat 'n argument ten gunste van die prosesbenadering in hierdie geval nie sonder meriete is nie.

Wanneer 'n probleem ten opsigte van die logiese vloei van die student se argument verduidelik word (Tesis 3:21), is die redigeerder se handeling egter meer sprekend van 'n prosesbenadering: "I understand that Barnwell refers to the target audience and their grasp of the target language. Then this part does not make sense because it is expected that the target audience will not understand Arabic (the source text) and it is fine to sound like rumblings. This would in my opinion only be applicable if some of the target audience had little or no formal education and struggled with written isiXhosa." Ooreenkomstig die EAC (2012:2) se riglyn om die onus op die student te plaas, word die inhoudelike probleem verduidelik maar die teks word nie gewysig nie.

Opmerkings wat met stilistiese kwessies verband hou, maak 26,47\% van die totale getal opmerkings in tesis 3 uit. Dit is opvallend dat die redigeerder die student telkens bedag maak op die noodsaaklikheid van helder formulering - soms ooreenkomstig die EAC se riglyne deur slegs te vra "[p]lease explain or rephrase" (Tesis 3:83), maar soms wel deur self te herformuleer en die student te vra om dit goed te keur (Tesis 3:44). Hierdie teenstrydigheid impliseer die

\footnotetext{
${ }^{49}$ Enkele kere ook "[n]ame all the authors the first time".

${ }^{50}$ Die kommentaar in tesis 3 is deurgaans in Engels. Engels is die student en die redigeerder se tweede taal, maar die student het 'n Afrikataal as eerste taal, terwyl die redigeerder se eerste taal Afrikaans is.
} 
gelyktydige toepassing van die proses- en produkbenadering. Die vraag wat hieruit voortvloei, is of verwarring by die redigeerder ten opsigte van sy/haar rol nie die oorsaak van 'n skynbaar ongemotiveerde wisseling tussen die twee benaderings is nie.

Kopieredigeringskwessies $(25,53 \%)$ neem ten opsigte van tesis 3 die derde plek in, en strukturele aspekte is vierde $(8,82 \%)$. Soos reeds genoem, is daar geen opmerkings wat met konsekwentheid verband hou nie.

Wat die tweede navorsingsvraag dus betref, is daar hierbo aangedui dat opmerkings wat verband hou met kopieredigering en inhoudelike kwessies die meeste voorkom (sien ook figuur 3). Die totale tellings vir strukturele en stilistiese redigering dui daarop dat hulle in vergelyking met die eerste twee kategorieë redelik min voorkom, en dat konsekwentheidskwessies baie selde in die opmerkings figureer. Met betrekking tot die internasionale riglyne in hierdie verband is daar opgelet dat daar in tesis 1 en 3 veral op die inhoudelike vlak hiervan afgewyk word, deurdat die redigeerders soms inhoud toevoeg, alhoewel daar ook bewyse is dat hulle dit nie in alle gevalle van probleme op inhoudelike vlak doen nie. In tesis 2 het die redigeerder weer in die slothoofstuk indringende inhoudelike vrae gevra wat eerder die studieleier se taak is. Dit wil voorkom (alhoewel die beperkte omvang van die studie weer eens hier beklemtoon moet word) asof redigeerders nie konsekwent is in hulle navolging van of ' $n$ produk- óf 'n prosesbenadering nie. Verdere navorsing sal nodig wees om aan te dui watter faktore hiertoe aanleiding gee. Is dit dalk die gevolg van rolverwarring, of bloot die gevolg van 'n niebewustheid van die twee benaderings (dat daar dus "intuitief" geredigeer word, eerder as met een spesifieke benadering in gedagte)?

\subsection{Navorsingsvraag 3}

Die derde navorsingsvraag het ten doel om die aard van die opmerkings wat aangebied word, te ondersoek. Meer spesifiek word daar gevra of daar verskillende soorte onderskei kan word en, indien wel, hoeveel van elke soort aangetref word.

Die opmerkings is almal kwalitatief bestudeer. Op grond daarvan of die redigeerder self 'n besluit oor ' $n$ bepaalde tekstuele probleem geneem het (al dan nie), is twee hoofkategorieë onderskei, wat verder in kleiner kategorieë verdeel is op grond van die taalhandeling in die opmerking. In totaal is elf kategorieë onderskei:

I Die redigeerder neem 'n besluit

1. 'n Wysiging word verduidelik: Die redigeerder bring 'n wysiging aan, maar verduidelik die relevante reël of beginsel sodat die student se begrip van die probleem verbeter word. Byvoorbeeld: "Daar moet altyd 'n spasie tussen die getal en die SI-eenheid wees. Ek sien op sommige plekke het jy dit wel so. Ek het dit konsekwent so toegepas." (Tesis $1: 3)$

2. Die student word gevra om wysiging(s) te hersien en goed te keur: Die redigeerder bring 'n wysiging aan en vra die student om dit na te gaan en goed te keur. Dit is egter onseker of hierdie aktiwiteit tot die student se eie leer sal lei. Byvoorbeeld: "Lees net weer hierdie gedeelte en kyk of jy met die veranderinge saamstem.” (Tesis 1:8) 
3. 'n Element word behou, maar 'n verduideliking word gegee: Die redigeerder behou die oorspronklike tekstuele element, maar verduidelik waarom hy/sy so besluit het. Die student se begrip van die hantering van die kwessie ter sprake kan derhalwe bevorder word, mits die student daaraan aandag skenk. Byvoorbeeld: "I understand that because this is a quotation the -ize form is used." (Tesis 3:4).

II Die redigeerder neem nie 'n besluit nie

1. 'n Verduideliking word gegee: Hier gaan dit daaroor dat kundige advies gegee word sodat die student se kennis en/of vaardighede uitgebrei word; die redigeerder bring egter nie self die wysiging aan nie en die student neem die besluit. Byvoorbeeld: "Die korrekte spelling binne 'n Britse/SA verband is ANALOGUE. Ek weet nie of jy dalk ANALOG (Amerikaanse spelling) verkies om 'n spesifieke vakkundige rede nie, so ek het dit nie verander nie. Ek sien die meeste ander studente het ook hierdie spelling in hulle tesisse [...]." (Tesis 1:12)

2. 'n Voorstel word gemaak: 'n Moontlike wysiging (of wysigings) word voorgestel; die student besluit self om dit te aanvaar of nie. Byvoorbeeld: "OF 'of conducting this research', OF '[of] carrying out this project', of so iets." (Tesis 1:26)

3. Die student word herinner: Die student word daaraan herinner om self sekere aspekte na te gaan. Byvoorbeeld: "Check the quotation marks very carefully in this paragraph and make sure of direct quotations." (Tesis 2:56)

4. 'n Vraag word gestel: 'n Vraag word aan die student gestel sodat hy/sy self oor die besondere aspek moet besin en self antwoorde moet vind. Byvoorbeeld: "Is dit nodig vir 'bold' en 'italics' hier?" (Tesis 1:23)

5. 'n Probleem word verduidelik: 'n Bepaalde tekstuele probleem word verduidelik, maar sonder om die oplossing te verskaf. Die student werk self om die verbetering aan te bring. Byvoorbeeld: "But there are only six students" na aanleiding van die student se stelling "[i]t must be noted that six of the students are coloured ... ." (Tesis 2:73)

6. 'n Opdrag word aan die student gegee: Die redigeerder gee die student die opdrag om self 'n sekere wysiging aan te bring. Die student neem self die verantwoordelikheid vir die korreksie. Byvoorbeeld: "Not right. Please copy correctly." (Tesis 2:61)

7. 'n Blote opmerking word aangebied: Hierdie soort opmerking behels dat die redigeerder slegs 'n bondige opmerking aanbied wat vervolgens deur die student geïnterpreteer moet word ten einde die probleem te begryp en dienooreenkomstig die korreksie te kan aanbring. Byvoorbeeld: "Citation" (Tesis 2:67), om die student te lei om te besef dat 'n verwysing ontbreek. Die redigeerder bring nie die wysiging aan nie.

8. 'n Probleem word uitgelig, maar die student moet besluit of dit geldig is: Die redigeerder wys die student daarop dat hy/sy 'n element as problematies beskou, maar die onus is op die student om te besluit of dit inderdaad 'n probleem is en dit op te los indien dit wel die geval is. Byvoorbeeld: "[...] here you refer to third person and in the next sentence to second person. It could be that I do not understand because I do not understand isiXhosa." (Tesis 3:48)

Tabel 4 gee besonderhede oor die voorkoms van die elf soorte opmerkings: 


\begin{tabular}{|c|c|c|c|c|c|c|c|c|c|c|c|c|c|}
\hline & \multicolumn{3}{|c|}{ Die redigeerder neem 'n besluit } & \multirow[b]{2}{*}{ 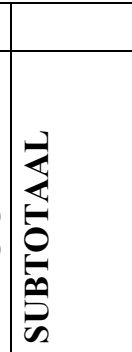 } & \multicolumn{8}{|c|}{ Die redigeerder neem nie 'n besluit nie } & \multirow[b]{2}{*}{ 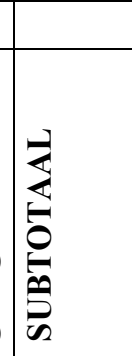 } \\
\hline & 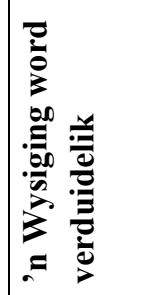 & 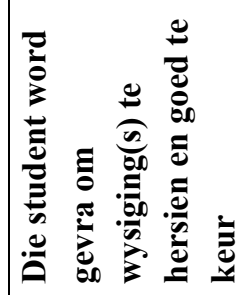 & 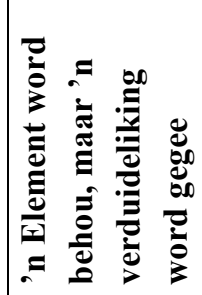 & & 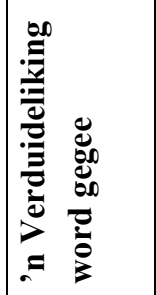 & 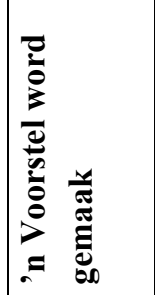 & 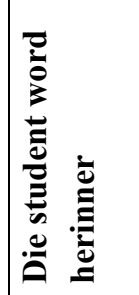 & 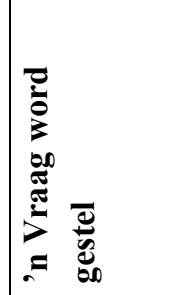 & 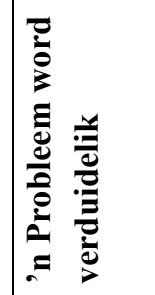 & 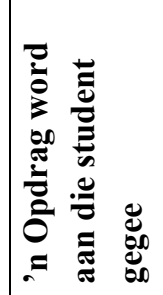 & 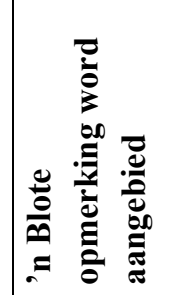 & 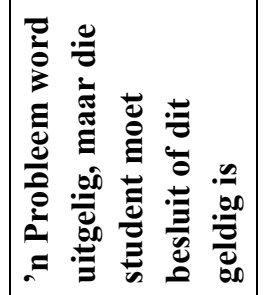 & \\
\hline $\begin{array}{l}\text { Tesis 1 } \\
(\mathrm{N}=56)\end{array}$ & $\begin{array}{l}3 \\
\mathbf{5 , 3 6 \%} \%\end{array}$ & $\begin{array}{l}2 \\
3,57 \%\end{array}$ & $\begin{array}{l}0 \\
0 \%\end{array}$ & $8,93 \%$ & \begin{tabular}{|l|}
8 \\
$14,29 \%$
\end{tabular} & \begin{tabular}{|l|}
12 \\
$21,43 \%$ \\
\end{tabular} & $\begin{array}{l}7 \\
12,5 \% \\
22\end{array}$ & $\begin{array}{l}19 \\
\mathbf{3 3}, \mathbf{9 3} \%^{53}\end{array}$ & \begin{tabular}{|l|}
5 \\
$\mathbf{8 , 9 3 \%}{ }^{54}$
\end{tabular} & $\begin{array}{l}0 \\
0 \%\end{array}$ & \begin{tabular}{|l|}
0 \\
$0 \%$
\end{tabular} & \begin{tabular}{|l|}
0 \\
$0 \%$
\end{tabular} & $91,08 \%$ \\
\hline $\begin{array}{l}\text { Tesis 2 } \\
(\mathrm{N}=196)\end{array}$ & $\begin{array}{l}0 \\
0 \%\end{array}$ & $\begin{array}{l}0 \\
0 \%\end{array}$ & $\begin{array}{l}0 \\
0 \%\end{array}$ & $0 \%$ & \begin{tabular}{|l|}
22 \\
$\mathbf{1 1}, \mathbf{2 2} \%^{55}$
\end{tabular} & $\begin{array}{l}3 \\
1,53 \% 56\end{array}$ & 4 & $\begin{array}{l}41 \\
\mathbf{2 0 , 9 2 \%}{ }^{58}\end{array}$ & \begin{tabular}{|l}
6 \\
$\mathbf{3 , 0 6 \%} \mathbf{\%}^{59}$
\end{tabular} & $\begin{array}{l}38 \\
19,59 \% \\
\end{array}$ & \begin{tabular}{|l|}
82 \\
$\mathbf{4 1 , 8 3 \%}{ }^{61}$
\end{tabular} & $\begin{array}{l}0 \\
0 \%\end{array}$ & $100 \%$ \\
\hline $\begin{array}{l}\text { Tesis } 3 \\
(\mathrm{~N}=34)\end{array}$ & $\begin{array}{l}7 \\
\mathbf{2 0 , 5 9} \%^{62}\end{array}$ & $\begin{array}{l}7 \\
20,59 \%\end{array}$ & $\begin{array}{l}1 \\
2,94 \%\end{array}$ & $44,12 \%$ & $\begin{array}{l}0 \\
0 \%\end{array}$ & \begin{tabular}{|l|}
5 \\
$14,71 \%{ }^{63}$
\end{tabular} & $\begin{array}{l}0 \\
0 \%\end{array}$ & $\begin{array}{l}3 \\
8,82 \%\end{array}$ & \begin{tabular}{|l}
3 \\
$\mathbf{8 , 8 2} \%$
\end{tabular} & $\begin{array}{l}3 \\
8,82 \%\end{array}$ & $\begin{array}{l}2 \\
\mathbf{5 , 8 8} \%\end{array}$ & $\begin{array}{l}3 \\
8,82 \%\end{array}$ & $55,87 \%$ \\
\hline
\end{tabular}

Tabel 4: Die voorkoms van die elf soorte opmerkings in die drie tesisse

\footnotetext{
${ }^{51}$ Een van hierdie opmerkings is ook ' $n$ verduideliking en een is ook ' $n$ vraag.

${ }^{52}$ Een van hierdie opmerkings is ook 'n vraag.

${ }^{53}$ Een van hierdie opmerkings is ook 'n voorstel.

${ }^{54}$ Een van hierdie opmerkings is ook 'n voorstel.

${ }^{55}$ Vier van hierdie opmerkings is ook opdragte; vier is ook blote opmerkings en vier is ook vrae.

${ }^{56}$ Een van hierde opmerkings is ook 'n opdrag en een is ook ' $n$ vraag.

${ }^{57}$ Een van hierdie opmerkings is ook 'n vraag.

${ }^{58}$ Vier van hierdie opmerkings is ook verduidelikings; twee is ook blote opmerkings; een is ook 'n verduideliking van 'n probleem; een is ook 'n herinnering en een is ook 'n voorstel.

${ }^{59}$ Een van hierdie opmerkings is ook 'n opdrag; een is 'n blote opmerking en een is ook 'n vraag.

${ }^{60}$ Vier van hierdie opmerkings is ook verduidelikings; vier is ook vrae; een is ook 'n voorstel; een is ook 'n verduideliking van 'n probleem en een is ook ' $\mathrm{n}$ herinnering.

${ }^{61}$ Drie van hierdie opmerkings is ook verduidelikings; een is ook ' $n$ verduideliking van 'n probleem en twee is ook vrae.

${ }^{62}$ Een van hierdie opmerkings is ook 'n voorstel.

${ }^{63}$ Een van hierdie opmerkings is ook 'n verduideliking van 'n wysiging en een is ook 'n verduideliking van 'n probleem.

${ }^{64}$ Een van hierdie opmerkings is ook 'n voorstel.
} 
Die verspreiding van die verskillende soorte opmerkings word grafies voorgestel in figuur 4:

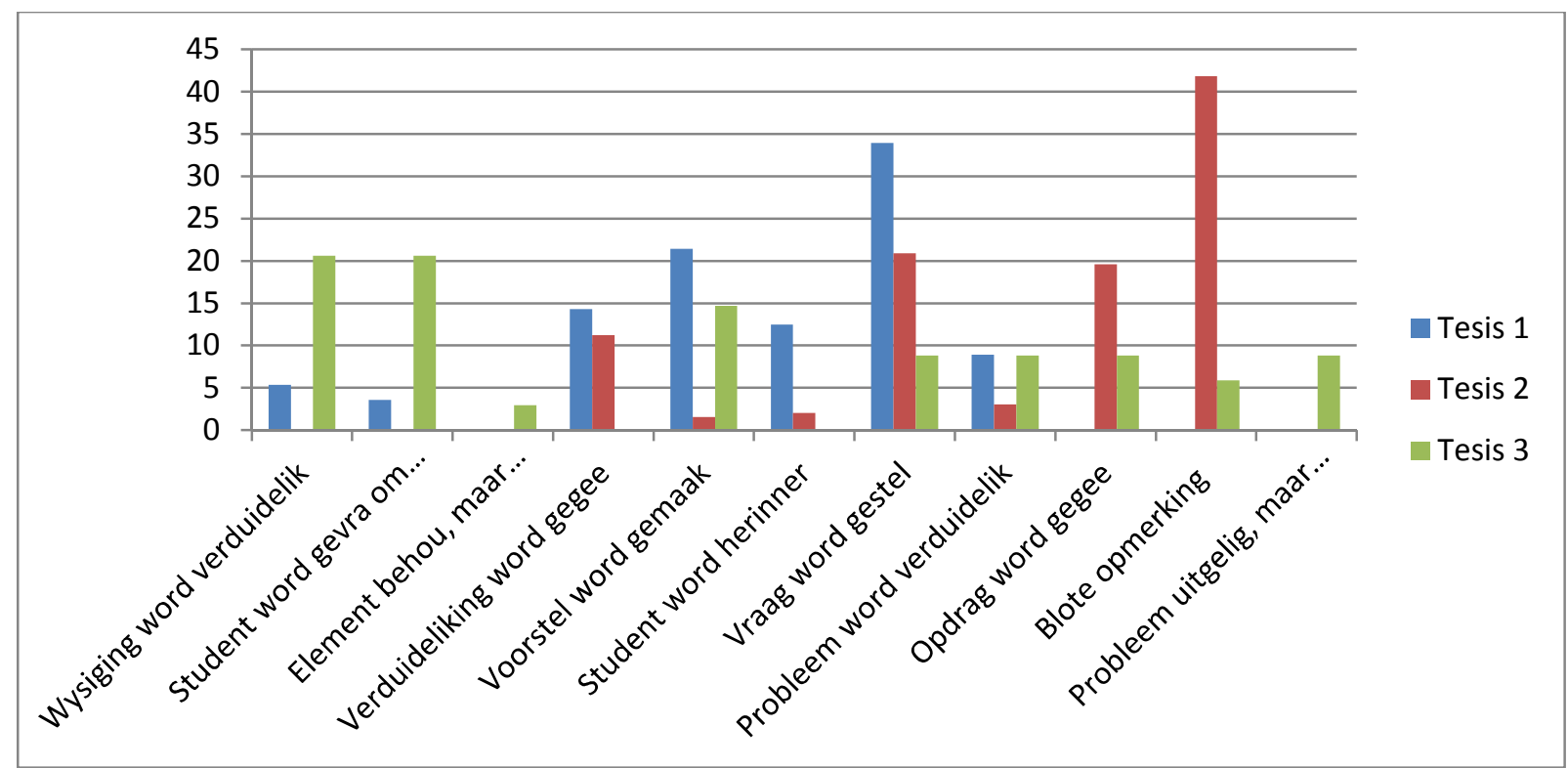

Figuur 4: Die voorkoms van die elf verskillende soorte opmerkings in die drie tesisse

Ten opsigte van die indeling van die verskillende soorte opmerkings moet daar genoem word dat heelwat oorvleueling tussen die soorte in tesis 1 en 2 opgelet word - 'n opmerking bestaan byvoorbeeld uit ' $n$ vraag sowel as 'n herinnering, soos gesien word in die volgende opmerking in tesis 1: "Deel van watter sin vorm hierdie frase [tussen die wiskundige vergelykings]?" Maak net seker hierdie gedeelte lees logies." In so 'n geval is die opmerking as beide 'n vraag en ' $n$ herinnering gereken, en om hierdie rede is die totaal van opmerkings in tabel 4 dan telkens ook meer as in tabel 2. In toekomstige studies kan dit oorweeg word om ook 'n kategorie vir "gemengde soorte" opmerkings te skep.

Verdere studies sal kan bevestig of die elf soorte wat op grond van die drie voorbeelde van geredigeerde tesisse geïdentifiseer is, wel 'n geldige indeling vir opmerkings is.

'n Interessante tendens wat opgelet is, is dat die meerderheid opmerkings in tesis 1 en 2 (onderskeidelik 91,08\% en 100\%) gegee word waar die redigeerder nié 'n redigeerbesluit neem nie, maar die besluit aan die student oorlaat. In tesis 3 word 44,12\% van die opmerkings gemaak wanneer 'n besluit wel geneem word, en 55,87\% word gemaak wanneer 'n besluit nie geneem word nie. Hierdie bevinding dui dus op 'n groter bewustheid van die student se eie refleksieproses in die geval van tesis 1 en 2.

\subsection{Navorsingsvraag 4}

Die laaste navorsingsvraag hou verband met die afleidings wat gemaak kan word oor die navolging van die produk- en/of die prosesbenadering.

In die eerste plek kan die resultate van die ondersoek na die getal opmerkings meehelp om hierdie vraag te beantwoord. Daar is reeds in die bespreking na aanleiding van die eerste

\footnotetext{
${ }^{65}$ My invoeging tussen blokhakies.
} 
navorsingsvraag aangedui dat al drie redigeerders wat in die ondersoek betrek is, wel gebruik maak van opmerkings tydens die redigering van akademiese tekste. Dit dui op 'n bewustheid van kommunikasie met die student, en sou versigtig geïnterpreteer kon word as dat die betrokke redigeerders wel na 'n prosesbenadering neig. 'n Kwalitatiewe ondersoek van die inhoud van die opmerkings kan egter help om hierdie bevinding te nuanseer.

Individuele verskille in die hantering van opmerkings deur die drie redigeerders is wel gevind, wat vervolgens deur die aanbieding van enkele kwalitatiewe opmerkings toegelig word. In die geval van tesis 1 (waar die tweede meeste opmerkings gevind is) is die opmerkings feitlik almal so geformuleer dat die student se eie leer moontlik gefasiliteer word. Die redigeerder open die moontlikheid tot selfrefleksie, en die student kan kies om betrokke te raak by die proses om beter te leer skryf. Die redigeerder van tesis 2 (wat die hoogste telling vir opmerkings het) beklemtoon veral tegniese kwessies soos die hantering van verwysings, en kennelik is die doel hiervan dat die student bemagtig word om hierdie kwessies voortaan self op te los. Tesis 3 het die minste opmerkings getoon. In hierdie geval het die redigeerder wel heelwat wysigings aangebring en die student is dan gevra om te hersien en goed te keur; daar is ook heelwat verduidelikings van wysigings wat aangebring is. Die indruk is dat die redigeerder die student eerder in die rol van 'n hersiener plaas; dit kom selfs voor asof die redigeerder sy/haar eie besluite moet regverdig. Alhoewel daar dus tog interaksie met die student is (weliswaar minder as in die geval van tesis 1 en tesis 2), is die interaksie nie soseer daarop gerig dat die student self probleme moet oplos nie en die indruk word geskep dat die redigeerder se eie redigeerproses na die voorgrond geskuif word. Daar is wel enkele gevalle waar voorstelle aangebied word waaroor die student kan nadink en kan besluit om veranderinge aan te bring, of nie (vergelyk: "I am of the opinion that less direct quotations would read better" [Tesis 3:7] en "[m]aybe this statement should be placed elsewhere in the text" [Tesis 3:9]).

Indien daar kwalitatief na die opmerkings in die drie tesisse gekyk word, word die vermoede bevestig dat die redigeerder van tesis 1 sowel as van tesis 2 oorwegend die prosesbenadering voorstaan, alhoewel die redigeerder van tesis 3 na 'n produkbenadering neig, soos wanneer wysigings reeds aangebring is en die opmerkings slegs die wysiging verduidelik. Terwyl dit eerder die redigeerder van tesis 3 se eie redigeerproses is wat op hierdie manier sigbaar raak, is die feit dat die redigeerder deur middel van opmerkings met die student kommunikeer, in beginsel wel 'n aanduiding van 'n prosesgerigte benadering, maar met die kwalifikasie dat die student se betrokkenheid by sy/haar skryfwerk nie noodwendig die hoofdoelstelling van die opmerking is nie. Die verduideliking van 'n wysiging kan die student se leer ten doel hê, maar die gevaar bestaan dat die student in die praktyk bloot die opmerking ignoreer. Voorts kan die verduidelikings ook geïnterpreteer word as teken van die redigeerder se geneigdheid om sy/haar wysigings te verdedig en om die student in die posisie van hersiener te plaas. Hierdie neigings kan 'n redigeerder se optimale benutting van die prosesbenadering in die gedrang bring.

In die tweede plek kan die soorte tekstuele probleme wat hanteer is, tesame met 'n vergelyking van die redigeerder se aktiwiteite met die internasionale riglyne rakende die etiese hantering van sekere kategorieë, ook meehelp om die redigeerder se gerigtheid te beskryf.

In tesis 1 word probleme ten opsigte van inhoud en struktuur veral deur middel van voorstelle, verduidelikings en vrae hanteer. Wanneer herhaling (dus 'n probleem op inhoudelike vlak) opgelet word, verduidelik die redigeerder die probleem: "Hierdie afdeling is met die uitsondering van ' $\mathrm{n}$ sin of twee presies dieselfde as afdeling 3.3. Hierdie afdeling moet egter 
fokus op die 'recommendations en conclusions' ..." (Tesis 1:65). Dit kom enkele kere voor asof die redigeerder die riglyne van die EAC oorskry, soos deur die opmerking wat aan die einde van die eerste hoofstuk aangebied word: "Ek sou hier net 'n paragraaf of twee insit om die hoofstuk af te rond en dit te koppel aan die res van die tesis. Dalk 'n probleemstelling of doelstelling wat net weer uitgelig word en moontlik 'n uiteensetting van hoofstukke wat volg? Dit eindig op die oomblik 'n bietjie stomp" (Tesis 1:7). Alhoewel standaard B5 (weglatings, byvoegings) ${ }^{66}$ wel volgens die EAC se riglyne met behulp van 'n opmerking hanteer mag word, is die vraag hier of die redigeerder nie moontlik te veel leiding gee nie, oftewel, die rol van die studieleier begin vervul nie. Die teenvraag is egter of studieleiers noodwendig altyd kundig genoeg is wat betref akademiese skryfvaardighede, en of daar nie gewerk moet word in die rigting van die verruiming van die redigeerder se rol om ook leiding op die vlak van teksbou (dus die aanbieding van die inhoud en die struktuur) te verskaf nie. Kruger en Bevan-Dye (2013) het egter reeds bevind dat studieleiers tans nie te vinde is vir ' $n$ redigeerpraktyk waar die redigeerder hulp en leiding ten opsigte van inhoudelike en strukturele kwessies aanbied nie, wat uiteraard 'n ongenuanseerde oproep om die verruiming van die redigeerder se rol problematiseer. ${ }^{67}$

Ten opsigte van kopieredigering is daar in tesis 1 ook heelwat opmerkings, wat veral herinneringe, vrae en raad insluit: "Maak net seker jy noem hierdie volledige name wanneer jy dit die eerste keer in jou tesis bekendstel" (Tesis 1:62), “[t]enses korrek hier?" (Tesis 1:46) en "[d]aar moet altyd 'n spasie tussen die getal en die SI-eenheid wees ..." (Tesis 1:3). Hieruit is dit duidelik dat die redigeerder dit ten doel het om die student te bemagtig om beter te kan skryf.

Die volgende "tegnieke" wat die redigeerder gebruik, is opgelet:

- Vrae word gestel sonder om die "regte" antwoorde te gee - die redigeerder gee soms twee opsies en die student neem self die besluit

- Voorstelle word gegee, maar sonder dat dit soseer die "oplossing" is - die redigeerder gee dikwels ook ('n) alternatiewe oplossing(s)

- Verduidelikings word aangebied (byvoorbeeld van bepaalde taalreëls) en die student los die probleem dan self op

- Probleme word verduidelik maar sonder om dit op te los

- Herinneringe word aangebied sodat die student sal onthou om self sekere wysigings aan te bring

Opsommend is dit dus duidelik dat die redigeerder van tesis 1 die prosesbenadering volg en ook op praktiese vlak daaraan uitvoering gee tydens die redigeerproses.

In tesis 2 het inhoudelike en kopieredigeringskwessies die meeste aandag geniet. By nadere ondersoek spreek die opmerkings van 'n beklemtoning van tegniese kwessies - die korrekte hantering van verwysings geniet veral aandag, soos hierbo genoem is. Die redigeerder dui aan wanneer 'n verwysing heeltemal ontbreek ("Citation" [Tesis 2:3]) sodat die student dit self op die regte plek, in die regte formaat, kan aanbring. Soms word daar verduidelik hoe om 'n bestaande verwysing te korrigeer: "Not in references. Do not use this as citation. Use the name of the relevant government department and the year" (Tesis 2:3). Eersgenoemde opmerking is

\footnotetext{
${ }^{66}$ Dus eintlik 'n inhoudelike kwessie, alhoewel die EAC dit as 'n strukturele kwessie interpreteer.

${ }^{67}$ Sien ook afdeling 1 waar die resultate van Kruger en Bevan-Dye (2013) se studie kortliks weergegee is.
} 
ooreenkomstig die EAC se riglyne oor ontbrekende bronverwysings (standaard D14), maar laasgenoemde opmerking lê buite die riglyne in die opsig dat die EAC-standaarde glad nie spesifiek voorsiening maak vir die formaat van verwysings nie - dus 'n tekortkoming in die EAC-standaarde. Wat tesis 2 betref, blyk 'n prosesbenadering uit die verantwoordelikheid wat op die student geplaas word om die bronverwysings self te versorg. Wat die korreksie van taalfoute betref, dui 'n analise van die wysigings egter aan dat taalfoute oorwegend gekorrigeer word sonder om die reëls te verduidelik, wat ten opsigte van hierdie aspek op 'n produkbenadering dui.

Die redigeerder se tegnieke wat in tesis 2 opgemerk is, behels:

- 'n Blote opmerking word aangebied wat deur die student geïnterpreteer word en waarna hy/sy die korreksie moet aanbring

- Die student ontvang opdragte om korreksies aan te bring

- Vrae en opdragte, maar ook raad word gekombineer

Waar die redigeerder van tesis 1 se styl baie ondersteunend is, neig die styl van die redigeerder van tesis 2 om meer direk, opdraggewend en teregwysend te wees. Opsommend kan die redigeerder van tesis 2 gesien word om 'n prosesbenadering in sy/haar werk te weerspieël, maar die hantering van sommige korreksies dui eerder op 'n produkbenadering - veral wanneer byvoorbeeld die hantering van kopieredigeringsaspekte met soortgelyke gevalle in tesis 1 vergelyk word.

Daar is reeds genoem dat die redigeerder van tesis 3 daartoe neig om die student in die rol van die hersiener van die wysigings te plaas. Ook word die EAC se riglyne oorskry wanneer die redigeerder ontbrekende inligting byvoeg en die student vra om dit goed te keur.

Die tegnieke wat by redigeerder 3 waargeneem is, dui op 'n gekombineerde produk- en prosesbenadering:

- Wysigings word aangebring en dan toegelig

- Voorstelle word aangebied

- Vrae word gestel

In die gevalle waar wysigings toegelig word, spreek die opmerking van 'n verskuiwing op die kontinuum in die rigting van die produkbenadering. In hierdie gevalle is die bedoeling waarskynlik dat die student oor die kwessie nadink en byvoorbeeld evalueer of sy/haar oorspronklike stelling wel nodig is: "I do not think it is necessary to mention this" (Tesis 3:12) na aanleiding van inligting wat geskrap is. Alhoewel dit in die praktyk kan gebeur dat die student bloot die wysiging aanvaar en die opmerking ignoreer, kan daar nietemin geredeneer word dat sulke opmerkings wel kritiese nadenke kan stimuleer, en daarom kan die potensiaal daarvan om leer by die student te bewerkstellig, nie bloot genegeer word nie. Terselfdertyd is daar opmerkings wat spesifiek kritiese nadenke by die student wil stimuleer, en dus as prosesgerig beskou kan word. Die volgende opmerking bied byvoorbeeld 'n voorstel aan wat die student se denke probeer rig om inligting toe te voeg: "Perhaps you should put this into context ..." (Tesis 3:59). Dieselfde soort stimulus tot selfrefleksie word gesien in 'n vraag wat die student laat besef dat hy/sy fouteer: "Why are the capital letters used so inconsistently?" (Tesis 3:51). Ook hier behoort die student die oplossing te soek en die korreksies aan te bring. 
Derdens kan die soorte opmerkings waarvan die redigeerders gebruik gemaak het, ook meehelp om afleidings oor die redigeerbenadering te maak.

Soos reeds onder die resultate van die derde navorsingsvraag genoem is, word die meerderheid opmerkings in tesis 1 en 2 (onderskeidelik 91,08\% en 100\%) gegee waar die redigeerder nié 'n redigeerbesluit neem nie, maar die besluit aan die student oorlaat. In tesis 3 word 44,12\% van die opmerkings gemaak wanneer 'n besluit wel geneem word, en 55,87\% word gemaak wanneer 'n besluit nie geneem word nie. Hierdie bevinding kan geïnterpreteer word as dat die redigeerders van tesis 1 en 2 sterker klem lê op die student se eie betrokkenheid en besluitneming as die redigeerder van tesis 3 , alhoewel die meerderheid van die opmerkings in tesis 3 steeds gegee word sonder dat 'n besluit deur die redigeerder geneem word. Hiervolgens weerspieël al drie geredigeerde tesisse 'n prosesgerigte benadering - tesis 1 en 2 feitlik volkome, terwyl die oorwig in die geval van tesis 3 veel kleiner is.

Ten opsigte van tesis 1 blyk dit dat vrae die meeste voorkom (19), gevolg deur voorstelle (12), verduidelikings (8) en herinneringe (7) in onderskeidelik die tweede tot die vierde plek. Hierdie resultate suggereer 'n redigeerbenadering wat refleksie deur die student self wil stimuleer, alhoewel die aanbieding van voorstelle in die tweede plek tog 'n mate van 'n produkingesteldheid kan suggereer. Wanneer die voorstelle egter kwalitatief beskou word, blyk dit wel dat die redigeerder nooit voorskriftelik te werk gaan nie en eerder moontlike oplossings aanbied; die gereelde optrede van die woord "dalk" versterk dan ook die vermoede dat die voorstelle steeds die student se kritiese omgang met sy/haar skryfwerk wil stimuleer. Die aanbieding van heelwat verduidelikings gee nietemin blyke daarvan dat die redigeerder daarop ingestel is dat die student self sekere vaardighede moet aanleer.

In tesis 2 kom opmerkings wat as "bloot opmerkings" beskryf kan word, die meeste voor (82), gevolg deur vrae (41), dan opdragte (38) en dan verduidelikings (22). Baie oorvleueling word egter gevind. ${ }^{68}$ 'n Kombinasie van 'n blote opmerking en 'n verduideliking van die probleem word byvoorbeeld in die volgende voorbeeld opgelet: "Not in references. Author, year and page number" (Tesis 2:35). Hier is die eerste sin die verduideliking van 'n probleem, gevolg deur 'n blote opmerking wat deur die student geïnterpreteer moet word. Hierdie enkele opmerking betrek twee probleme: die bron word nie in die bronnelys gelys nie, en die outeur, jaar en bladsynommer word nie in die inteksverwysing verskaf nie (slegs die afgekorte titel word gegee). Die student moet dus self die betrokke bron by die bronnelys voeg, en ook die inteksverwysing korrigeer. Dit is beduidend dat die redigeerder nie 'n voorbeeld aanbied van hoe die inteksverwysing behoort te lyk nie - die student word dus gedwing om self die formaat na te slaan en die wysiging aan te bring.

Die feit dat blote opmerkings so besonder sterk verteenwoordig word (82 uit die totaal van 196), kan ook daarop dui dat die redigeerder die student juis self wil laat nadink. Daar kan egter gevra word of die gebruik van sulke kriptiese opmerkings in alle gevalle suksesvol sal wees, omdat 'n redelike groot inset van die student verwag word - die opmerking moet eerstens geïnterpreteer word alvorens die korreksie oorweeg en aangebring kan word. 'n Nadere ondersoek dui egter aan dat spesifiek die opmerkings "[p]age number" en "[c]itation" baie dikwels voorkom. 'n Nagraadse student behoort met min moeite te kan aflei dat hierdie aspekte ontbreek, sodat die beswaar van té kriptiese opmerkings hier nie geldig skyn te wees nie.

\footnotetext{
${ }^{68}$ Sien besonderhede in die voetnote by tabel 4.
} 
Verdere studies sou byvoorbeeld kon nagaan of te kriptiese opmerkings in die praktyk tot gebrekkige begrip deur die student - gevolg deur ontoereikende korreksies - kan lei.

Tesis 3 word gekenmerk deur min oorvleueling. Die soort opmerking waarin die student gevra word om wysigings te hersien en goed te keur, kom saam met die verduideliking van wysigings die meeste voor (beide 7). Voorstelle (5) kom hiernaas die meeste voor. Hierdie resultate suggereer dat die betrokke redigeerder moontlik 'n redelik tentatiewe redigeerstyl het, wat daarvoor sorg dat die student in die rol van "hersiener" van die wysigings geplaas word. Eerder as wat die student se aktiewe leer deur byvoorbeeld vrae gestimuleer word, bied die redigeerder wysigings aan wat die student dan kan goedkeur of verwerp. Nietemin dui die enkele vrae (3) asook die verduideliking van probleme (3) tog op 'n beperkte bewustheid van die student se leerproses.

\section{Slotsom}

Ten opsigte van die navorsingsvraag blyk dit dat opmerkings wel benut word, alhoewel die drie tesisse nie in dieselfde mate blyke gee van 'n benutting van opmerkings nie. Die basiese beskrywende statistiese gegewens wat vir hierdie drie gevallestudies verskaf is, kan egter nie beduidendheid aandui nie, en verdere studies met 'n groter en meer verteenwoordigende steekproef sal nodig wees. In beginsel dui die gebruik van opmerkings in die drie redigeerprojekte op ' $n$ aanwesigheid van die prosesbenadering, maar dit is nodig om die resultate van die kwalitatiewe ontledings te betrek om nuanses tot hierdie afleiding toe te voeg.

Die kwalitatiewe ontledings het aangedui dat die prosesbenadering nie suiwer toegepas word nie. Die individuele projekte is telkens 'n kombinasie van die twee benaderings, alhoewel die prosesbenadering in tesis 1 en 2 sterker teenwoordig is. In tesis 3 daarteenoor, is daar heelwat opmerkings wat na die produk-ekstreem op die kontinuum neig. Die resultate van die kwantitatiewe ondersoek na die elf geïdentifiseerde soorte opmerkings bevestig hierdie bevinding.

Verdere studies sal kan aandui of 'n hibriede benadering, soos in tesis 3, gereeld voorkom en indien wel, watter faktore so 'n benadering aanmoedig. Verdere studies sal ook kan aandui of sekere redigeeraktiwiteite die gevolg van 'n bewuste navolging van 'n bepaalde redigeerbenadering is. Daar sal ook in toekomstige studies aangetoon kan word of 'n hibridiese benadering wat deur teenstrydighede gekenmerk word, dalk die gevolg van redigeerders se verwarring oor hulle eie rol is.

Die drie redigeerders in die ondersoek blyk tot ' $n$ mate bewus te wees van die grense van etiese redigering sowel as van die belangrike rol wat deur die student self vervul moet word om sy/haar akademiese skryfwerk te versorg. Tog is daar gevalle waar die redigeerder die grens oorskry en 'n funksie begin vervul wat eerder dié van die studieleier is. Daar kan geargumenteer word dat die daarstel van deurdagte riglyne vir die Suid-Afrikaanse situasie redigeerders kan help om te weet wat die omvang van hulle ingrepe mag wees. Terselfdertyd kan sulke riglyne help om die verhouding tussen student, studieleier en redigeerder te omskryf en elk se onderskeie take uit te spel.

Hierdie ondersoek het veral implikasies op vier vlakke, wat ook rigtinggewend is vir verdere navorsing, professionele standaardiseringsaktiwiteite en die beplanning van opleiding. Eerstens 
moet die gevisualiseerde groter studie verder ondersoek instel na die vergestalting van die produk- en die prosesbenadering tydens akademiese redigering. Deelstudies binne hierdie projek kan insluit die bepaling van die beduidendheid van tendense wat in die huidige studie opgelet is, soos die verspreiding van opmerkings binne 'n tesis aan die hand van 'n meer verteenwoordigende steekproef. Ook kan die invloed van veranderlikes soos die vakgebied en die redigeerder se opleiding en/of ondervinding op die frekwensie en verspreiding van die opmerkings nagegaan word. Voorts kan ondersoeke onderneem word wat fokus op ander redigeeraktiwiteite as net die benutting van opmerkings - byvoorbeeld ondersoeke wat tekstuele wysigings self ondersoek en tendense karteer wat betref die soorte tekstuele probleme wat deur redigeerders opgelos word.

Tweedens behoort die rol van die redigeerder van akademiese tekste verdere aandag te ontvang en moet die vraag veral gestel word of die omskrywing van die akademiese redigeerder se taak nie dalk verruim moet word om hom/haar in staat te stel om meer advies aan te bied wat byvoorbeeld teksboukwessies betref nie. Hierdie vraag behoort teen die agtergrond van Kruger en Bevan-Dye (2013) se studie oor studieleiers se persepsies ondersoek te word, met die moontlikheid dat bestaande studieleidingsmodelle via gesprek uitgedaag kan word.

Derdens behoort riglyne (of standaarde) vir spesifiek die Suid-Afrikaanse situasie geformuleer te word, wat die rol van die studieleier asook die verhouding tussen studieleier, student en redigeerder sal formaliseer.

Laastens behoort die opleiding van redigeerders die eise van akademiese redigering as 'n spesifieke soort redigering te hanteer, sodat redigeerders in die praktyk toegerus is om hierdie soort tekste op 'n meer eenvormige wyse te hanteer, wat ook nie die grense van etiese redigering oorskry nie. Dit sal insluit riglyne oor die optimale benutting van opmerkings - wanneer dit aangedui is en watter vorm dit moet aanneem.

\section{Bronnelys}

Butcher, J., Drake, C. en Leach, M. 2006. Butcher's copy-editing: The Cambridge handbook for editors, copy-editors and proofreaders. Cambridge: Cambridge University Press.

Council of Australian Societies of Editors (CASE). 2013. Australian standards for editing practice [Internet]. Beskikbaar: http://iped-editors.org/site/DefaultSite/filesystem/documents/ ASEP\%20Imposed\%20booklet\%20version.pdf (11 Junie 2013)

Du Toit, P. en Smith-Müller, W. 2003. Stylboek: Riglyne vir paslik skryf. Pretoria: Van Schaik.

Editors' Association of Canada (EAC). 2009. Professional editorial standards [Internet]. Beskikbaar: http://www.editors.ca/files/public/PES-2009-FINAL.pdf (11 Junie 2013).

Editors' Association of Canada (EAC). 2012. Guidelines for ethical editing of theses/dissertations [Internet]. Beskikbaar: http://www.editors.ca/files/public/Guidelines Editing_Theses_2012-06-02_APPROVED.pdf (11 Junie 2013) 
Hansen, E. (elzetteh@sun.ac.za), 14 Februarie 2011. Terugvoering vanaf medewerkers. E-pos aan A. Lourens (alourens@sun.ac.za).

Hill, G. 2011. The art of querying. Workshop at SfEP conference. 26 September 2011. St Catherine's College, Oxford.

Institute of Professional Editors Limited (IPEd). 2010. Guidelines for editing research theses [Internet]. Beskikbaar: $\quad$ http://iped-editors.org/site/DefaultSite/filesystem/documents/ Guidelines\%20for\%20editing\%20research\%20theses.pdf (30 Mei 2013).

Kruger, H. en Bevan-Dye, A. 2010. Guidelines for the editing of dissertations and theses: A survey of editors' perceptions. Southern African Linguistics and Applied Language Studies 28(2): 153-169.

Kruger, H. en Bevan-Dye, A. 2013. The language editor's role in postgraduate research: A survey of supervisors' perceptions. South African Journal of Higher Education 27(4): 875-899.

Law, M. 2011. The development of core standards for editing in South Africa. Southern African Linguistics and Applied Language Studies 29(3): 275-292.

Linnegar, J. 2010. Report on editing theses workshop. Saturday, 13 November 2010, Royal Cape Yacht Club, Duncan Dock, Cape Town. E-pos aan Alta van Rensburg (avrens@sun.ac.za), aangestuur na Amanda Lourens (alourens@sun.ac.za).

Macdonald, M. 2008. Editing theses and dissertations. Part 1: Ethical issues. Editing Matters, Jan/Feb 2008: 3-4.

Mossop, B. 2007. Revising and editing for translators. 2de uitgawe. Manchester: St. Jerome.

Universiteit Stellenbosch Taaldiens. G.d. Redigering van jou tesis of navorsingsverslag [Internet]. Beskikbaar: http://www0.sun.ac.za/taalsentrum/assets/files/TaaldiensDokumente/ Tesisredigering 2013 kleur.pdf (18 Junie2013).

Van Aswegen, E.S. 2007. Postgraduate supervision: The role of the (language) editor: Sed quis custodiet ipsos custodes? South African Journal of Higher Education 21(8): 1139-1151. 